\title{
In situ-produced cosmogenic krypton in zircon and its potential for Earth surface applications
}

\author{
Tibor János Dunai ${ }^{1}$, Steven Andrew Binnie ${ }^{1}$, and Axel Gerdes ${ }^{2}$ \\ ${ }^{1}$ Institute of Geology and Mineralogy, University of Cologne, Zülpicher Str. 49b, 50674 Cologne, Germany \\ ${ }^{2}$ Institute for Geosciences, Goethe University Frankfurt, Altenhöferallee 1, 60438 Frankfurt am Main, Germany \\ Correspondence: Tibor János Dunai (tdunai@uni-koeln.de)
}

Received: 16 August 2021 - Discussion started: 20 August 2021

Accepted: 30 November 2021 - Published: 25 January 2022

\begin{abstract}
Analysis of cosmogenic nuclides produced in surface rocks and sediments is a valuable tool for assessing the rates of processes and the timing of events that shaped the Earth surface. The various nuclides that are used have specific advantages and limitations that depend on the time range over which they are useful, the type of material they are produced in and not least the feasibility of the analytical effort. Anticipating novel applications in Earth surface sciences, we develop in situ-produced terrestrial cosmogenic krypton $\left(\mathrm{Kr}_{\mathrm{it}}\right)$ as a new tool, the motivation being the availability of six stable and one radioactive isotope $\left({ }^{81} \mathrm{Kr}\right.$, halflife $229 \mathrm{kyr}$ ) and of an extremely weathering-resistant target mineral (zircon). We provide proof of principle that terrestrial $\mathrm{Kr}_{\text {it }}$ can be quantified and used to unravel Earth surface processes.
\end{abstract}

\section{Introduction}

Cosmogenic nuclides have become an important tool to address questions in Earth surface sciences and paleoclimatology (Dunai, 2010; Gosse and Phillips, 2001; Balco, 2020). These nuclides are produced by particles of the cosmic ray cascade in the atmosphere and in minerals (i.e. in situ) at or close to the Earth's surface (Dunai, 2010; Gosse and Phillips, 2001). Each of the currently applied in situ-produced cosmogenic nuclides, i.e. ${ }^{3} \mathrm{He},{ }^{10} \mathrm{Be},{ }^{14} \mathrm{C},{ }^{21} \mathrm{Ne},{ }^{26} \mathrm{Al},{ }^{36} \mathrm{Cl}$ and ${ }^{53} \mathrm{Mn}$, has specific benefits and limitations that are rooted in its half-life (or stability in the case of ${ }^{3} \mathrm{He}$ and ${ }^{21} \mathrm{Ne}$ ), the availability of suitable target minerals and our ability to measure the exceedingly low amounts produced (typically between 1-100 atoms per gram per year at sea level; Dunai,
2010). In space, production rates are at least 3 orders of magnitude higher than on Earth at ground level. Hence, many in situ-produced nuclides were initially developed in studies of extra-terrestrial material (e.g. meteorites, lunar rocks) some 30 years before they began to be used to transform quantitative Earth surface sciences. Cosmogenic krypton, ${ }^{78,80-86} \mathrm{Kr}$ (Marti et al., 1966; Gilabert et al., 2002; Marti, 1967) has not made this transition yet, despite having the potential. Krypton is the only noble gas that has stable $\left({ }^{78,80,82-84,86} \mathrm{Kr}\right)$ and short-lived radioactive isotopes $\left({ }^{81,85} \mathrm{Kr}\right)$ that are produced by cosmic rays (Gilabert et al., 2002; Marti et al., 1966). An exception is cosmogenic argon $\left({ }^{36,37,38,39} \mathrm{Ar}\right.$; Renne et al., 2001; Niedermann et al., 2007; Saldanha et al., 2019), which, due to inherent limitations (Renne et al., 2001; Dunai, 2010), still awaits widespread application to Earth surface sciences (Oostingh et al., 2017). With a half-life $\left(t_{1 / 2}\right)$ of $229 \pm 11 \mathrm{kyr}$ (Baglin, 2008), ${ }^{81} \mathrm{Kr}$ is particularly attractive for geomorphological applications; however, only the cosmogenic ${ }^{81} \mathrm{Kr}$ produced in the atmosphere has been used in Earth sciences to date, as a dating tool for old ice and groundwater (Buizert et al., 2014; Sturchio et al., 2004).

\subsection{In situ-produced extra-terrestrial krypton}

In situ-produced extra-terrestrial krypton, $\mathrm{Kr}_{\text {iet }}$, in meteorites has been measured for over 50 years (Marti et al., 1966; Marti, 1967). For instance, the $\mathrm{Kr}-\mathrm{Kr}$ dating method of meteorites (Marti, 1967) is routinely applied (e.g. Strashnov and Gilmour, 2013; Leya et al., 2015). All stable and moderately long-lived Krypton isotopes (including ${ }^{85} \mathrm{Kr}, t_{1 / 2}=$ 10.7 years, Lerner, 1963) are produced via spallation reactions (Gilabert et al., 2002) that are responsible for cosmogenic production. The main target elements for spallogenic 
$\mathrm{Kr}$ production are $\mathrm{Rb}, \mathrm{Sr}, \mathrm{Y}, \mathrm{Zr}$ and $\mathrm{Nb}$ (Gilabert et al., 2002; Marti et al., 1966; Leya et al., 2015), which have isotopes similar in mass (slightly higher masses) to $\mathrm{Kr}$ isotopes. The minimum energies for neutrons producing $\mathrm{Kr}$ isotopes by spallation from $\mathrm{Zr}$ are $50-100 \mathrm{MeV}$ (higher end of range for isotope masses $<83$; Gilabert et al., 2002).

\subsection{In situ-produced terrestrial krypton}

In meteorites, $\mathrm{Rb}, \mathrm{Sr}, \mathrm{Y}, \mathrm{Zr}$ and $\mathrm{Nb}$ are trace constituents at the ppm level (Mason et al., 1976; Leya et al., 2004). A key conceptual step in utilizing in situ-produced terrestrial krypton, $\mathrm{Kr}_{\mathrm{it}}$, is the realization that, due to the geochemical differentiation of the Earth, the target elements for cosmogenic $\mathrm{Kr}$ form discrete minerals or are enriched in other minerals. For example: $\mathrm{Rb}$ is enriched in biotite; $\mathrm{Sr}$ forms strontianite $\left(\mathrm{SrCO}_{3}\right)$, strontian calcite (up to several \% $\mathrm{Sr}$ ) or coelestine $\left(\mathrm{SrSO}_{4}\right)$; Y forms xenotime $\left(\mathrm{YPO}_{4}\right)$, $\mathrm{Zr}$ zircon $\left(\mathrm{ZrSiO}_{4}\right)$ and baddeleyite $\left(\mathrm{ZrO}_{2}\right)$; and $\mathrm{Nb}$ is present in columbite $\left((\mathrm{Fe}, \mathrm{Mn}, \mathrm{Mg}) \mathrm{Nb}_{2} \mathrm{O}_{6}\right)$. Enrichments in these minerals over the concentrations in meteorites may be of the order of $10^{3}-10^{4}$, similar in magnitude to the cosmic ray flux differences between space and on Earth (Dunai, 2010), but in a reversed sense. The lower cosmic ray flux on Earth is thus fully compensated by the higher target-element concentrations and so determination of $\mathrm{Kr}_{\text {it }}$ in these minerals should be as easily attainable as $\mathrm{Kr}_{\text {iet }}$ is in meteorites.

Given the list of potential minerals, it appears that only zircon is near-ubiquitous on the Earth's surface, albeit as an accessory mineral. Therefore, in the following we focus on zirconium as the target element and zircon as the target mineral. Considerations for other target elements or minerals are conceptually similar.

\subsubsection{Spallation}

As a first approximation of terrestrial production of krypton by spallation of zirconium due to neutrons we use thicktarget $1600 \mathrm{MeV}$ proton-irradiation experiments (Gilabert et al., 2002) and derive ${ }^{83} \mathrm{Kr}$ as the most abundant $\mathrm{Kr}_{\text {it }}$ isotope, followed by ${ }^{82} \mathrm{Kr},{ }^{81} \mathrm{Kr},{ }^{80} \mathrm{Kr},{ }^{78} \mathrm{Kr},{ }^{84} \mathrm{Kr},{ }^{85} \mathrm{Kr}$ and ${ }^{86} \mathrm{Kr}$ ( $1: 0.81: 0.67: 0.58: 0.29: 0.22: 0.005: 0.004$; for shielding depth $\geq 49.2 \mathrm{~g} \mathrm{~cm}^{-2}$; Fig. 1).

The dominant reaction pathway for spallogenic $\mathrm{Kr}$ production on zircon appears to be of the type $\operatorname{Zr}(n, 2 \alpha+x n) \mathrm{Kr}$ (with neutron multiplicities $x=0,1,2,3,4,5$ ). This may be deduced from (i) the minimum energies required and (ii) the $\mathrm{Zr}$ and spallogenic $\mathrm{Kr}$ isotope abundances (Gilabert et al., 2002). At the low energy end (50 MeV; Gilabert et al., 2002) only $\alpha$ emissions are possible. This is due to the energy bonus of the emission of $\alpha$ particles as compared the emission of individual nucleons, which is $28.3 \mathrm{MeV}$ per $\alpha$ particle (Dunai, 2010); the binding energies of nucleons (neutrons and protons) are $8.7 \mathrm{MeV}$ in this mass range (Soppera et al., 2014), protons additionally requiring $>8$ to overcome

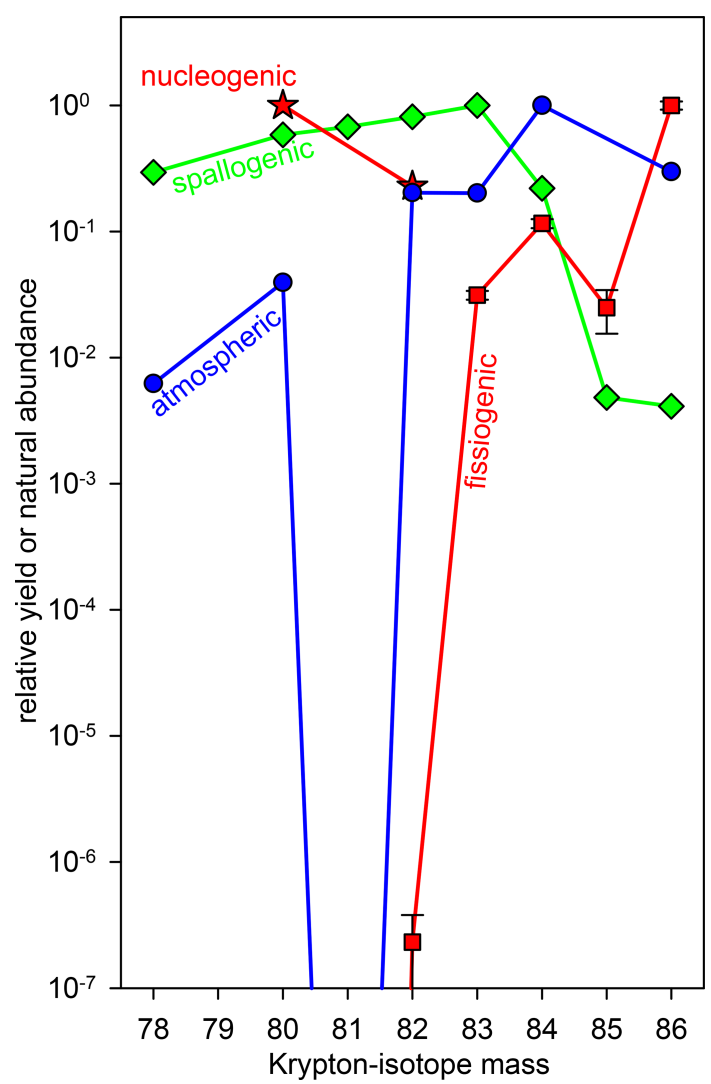

Figure 1. Relative abundances of krypton isotopes in natural sources of krypton. Normalized krypton abundances (normalized to the most abundant isotope of a given source) of atmospheric (Aregbe et al., 1996; Sturchio et al., 2004), fissiogenic (from spontaneous fission of ${ }^{238} \mathrm{U}$; JAEA, 2011), nucleogenic (thermal neutron capture by bromine; Soppera et al., 2014; Kendrick, 2012) and spallogenic (proton-irradiation experiments, zirconium, $\geq 49 \mathrm{~g} \mathrm{~cm}^{-2}$ shielding; Table 2a of Gilabert et al., 2002) krypton. Most geological material on Earth contains atmospheric krypton, with all large geochemical reservoirs (i.e. mantle, crust) containing krypton of atmospheric composition.

the Coulomb barrier. Consequently, individual separation of two neutrons and two protons from a nucleon in this mass ranges would require an energy input from a cosmic ray particle of $\geq 50.8 \mathrm{MeV}$, whereas the separation of an $\alpha$ particle requires only $\geq 22.5 \mathrm{MeV}$. The most abundant spallogenic $\mathrm{Kr}$ isotope ${ }^{83} \mathrm{Kr}$ may be produced on the lightest and most abundant stable $\mathrm{Zr}$ isotope ${ }^{90} \mathrm{Zr}(51.45 \%)$ via the energetically favourable $(n, 2 \alpha)$ reaction (Fig. 2), albeit also on all other $\mathrm{Zr}$ isotopes via $(n, 2 \alpha+x n)$ reactions $(x=1,2,4,5)$. Kr isotopes with masses smaller than 83 require in any case the additional separation of one or more neutrons, meaning higher minimum energies of the incoming neutrons are needed (Gilabert et al., 2002), which in turn explains the successively lower production as masses decrease. The lower production of ${ }^{84} \mathrm{Kr}$ is commensurate with the lower cumulative abundance of its target nuclides ${ }^{91,92,94} \mathrm{Zr}$ and, in the case of ${ }^{92} \mathrm{Zr}$ 
and ${ }^{94} \mathrm{Zr}$, the requirement for the additional separation of one or two neutrons, respectively. The conspicuous relative rarity of spallogenic ${ }^{86} \mathrm{Kr}$ (Fig. 1), despite it being the $\mathrm{Kr}$ isotope closest in mass to $\mathrm{Zr}$, probably stems from the fact that there is no $(n, 2 \alpha+x n)$ pathway to produce it on stable $\mathrm{Zr}$ isotopes (Fig. 2).

\subsubsection{Negative muon capture}

Muons $\left(\mu^{-}, \mu^{+}\right)$, which are products from cosmic ray interactions in the Earth's atmosphere (Dunai, 2010; Stone et al., 1998), may also contribute to $\mathrm{Kr}$ production. Captured negative muons neutralize one proton and deliver $106 \mathrm{MeV}$ (the mass of a muon at rest) to the nucleus (Dunai, 2010; Stone et al., 1998). Much of this energy is carried away by neutrino emission $\left(v_{\mu}\right)$, such that on average close to $20 \mathrm{MeV}$ is available for nuclear evaporation (Measday, 2001; Lifshitz and Singer, 1980). In the mass range of $\mathrm{Zr}$ isotopes, captured negative neutrons may induce $\left(\mu^{-}, v_{\mu}+\alpha\right)$ reactions with probabilities close to $10^{-4}$ (Wyttenbach et al., 1978). Production of krypton by muon capture on zirconium would require the separation of one additional charged particle, following reactions of the type $\left(\mu^{-}, v_{\mu}+2 \alpha x n\right)$ and $\left(\mu^{-}, v_{\mu}+\alpha p x n\right)$, with $x=0$ to 4 . The $\left(\mu^{-}, v_{\mu}+2 \alpha \times n\right)$ reaction would produce a radioactive $\mathrm{Br}$ isotope decaying into a $\mathrm{Kr}$ isotope (Fig. 2). This would work for $\mathrm{Kr}$ isotopes with mass $\leq 84$, except for ${ }^{81} \mathrm{Kr}$ as it is shielded by stable ${ }^{81} \mathrm{Br}$. Using the Coulomb barrier and reaction probability observed by Wyttenbach et al. (1978), we estimate that probabilities for $\left(\mu^{-}\right.$, $\left.v_{\mu}+\alpha p\right)$ and $\left(\mu^{-}, v_{\mu}+2 \alpha\right)$ reactions are at least $10^{2}$ to $10^{3}$ lower than a $\left(\mu^{-}, v_{\mu}+\alpha\right)$ reaction for a given $\mathrm{Zr}$ isotope. The required separation energy for emission of one or more neutrons ( $\sim 8.7 \mathrm{MeV}$ per neutron; see above) would decrease the likelihood of this even further (Lifshitz and Singer, 1980). Hence, the probability of negative muons captured by $\mathrm{Zr}$ isotopes producing $\mathrm{Kr}$ isotopes is smaller than $10^{-6}$. Of muons coming to rest in zircon, $35 \pm 4 \%$ is captured by $\mathrm{Zr}$ (von Egidy and Hartmann, 1982), and so the $\mathrm{Kr}$ isotope yield from muon capture by $\mathrm{Zr}$ in zircon is less than $0.3 \mathrm{ppm}$. This translates into less than $10^{-6}$ atoms $\mathrm{g}^{-1} \mathrm{yr}^{-1}$ at sea level and high latitude (Stone et al., 1998).

\subsubsection{Interfering components}

Geochemical components that may interfere with the analysis of cosmogenic krypton are the products of spontaneous fission of ${ }^{238} \mathrm{U}$ (fissiogenic krypton, $\mathrm{Kr}_{\mathrm{fis}}$ ) and neutron capture by bromine (nucleogenic krypton, $\mathrm{Kr}_{\text {nuc }}$ ). These may become important when analysing $\mathrm{U}$ - or Br-rich minerals (Eikenberg et al., 1993; Honda et al., 2004; Ruzie-Hamilton et al., 2016; Kendrick, 2012). Fission yields of krypton isotopes heavier than ${ }^{81} \mathrm{Kr}$ increase with increasing mass such that ${ }^{86} \mathrm{Kr}_{\text {fis }}$ is the most abundant, and the yield of ${ }^{82} \mathrm{Kr}_{\text {fis }}$ is negligible (Fig. 1; Eikenberg et al., 1993; JAEA, 2011). Spontaneous fission of ${ }^{238} \mathrm{U}$ does not produce $\mathrm{Kr}$ isotopes lighter than ${ }^{82} \mathrm{Kr} .{ }^{80} \mathrm{Kr}_{\text {nuc }}$ and ${ }^{82} \mathrm{Kr}_{\text {nuc }}$ may be produced by reactions on bromine, ${ }^{79} \mathrm{Br}(n, \gamma){ }^{80} \mathrm{Kr}$ and ${ }^{81} \mathrm{Br}(n, \gamma)^{82} \mathrm{Kr}$ (reaction cross sections for thermal neutrons are 10.32 and 2.36 barn, respectively; Soppera et al., 2014). Bromine concentrations are low in silicate minerals (Kendrick, 2012; Ruzie-Hamilton et al., 2016; Teiber et al., 2015) but commonly not well constrained. The major geochemical reservoirs of Earth (e.g. the mantle) contain krypton close to atmospheric composition $\left({ }^{80} \mathrm{Kr} 2.25 \% ;{ }^{82} \mathrm{Kr} 11.6 \% ;{ }^{83} \mathrm{Kr} 11.5 \%\right.$; ${ }^{84} \mathrm{Kr} 57.0 \%$; ${ }^{86} \mathrm{Kr} 17.3 \% ;{ }^{78} \mathrm{Kr} 0.35 \% ;{ }^{81} \mathrm{Kr} 0.5 \mathrm{ppt}$; Buizert et al., 2014; Aregbe et al., 1996). Natural krypton is rarely measured in geological material due to the anticipated consistency of these values (Broadley et al., 2020; Trieloff et al., 2000)

\subsubsection{Test of feasibility}

To test the feasibility of using $\mathrm{Kr}_{\mathrm{it}}$ for Earth surface science applications, we analysed a suite of zircon samples from near-surface sediment and bedrock with a wide range of anticipated exposure histories. The sediment samples are zircon megacrysts from kimberlitic, carbonatitic and metamorphic source rocks from locations in Australia (Mud Tank carbonatite; Crohn and Moore, 1984; Currie et al., 1992), Tanzania (Singida kimberlite field and Ubendian-Usagaran metamorphic belt; Mannard, 1962; Kabete et al., 2012) and Germany (Ebersbrunn diatreme, Vogtland; Schmidt et al., 2013; Modalek et al., 2009). The bedrock samples are from glacially scoured surfaces and a block from the Grimsel Pass, Switzerland (Wirsig et al., 2016). We use this suite of samples (see Sect. 2 for details) to constrain terrestrial production ratios of $\mathrm{Kr}_{\text {it }}$ isotopes, to cross-calibrate production rates with a well-established cosmogenic nuclide $\left({ }^{10} \mathrm{Be}\right)$, and to provide the first applications by constraining histories of burial and exposure in arid and temperate regions.

\section{Sample materials}

\subsection{MUD}

These zircons are from the Mud Tank carbonatite, Northern Territories, Australia $\left(23^{\circ} 0^{\prime} 47^{\prime \prime} \mathrm{S} ; 1^{\circ} 4^{\circ} 16^{\prime} 45^{\prime \prime} \mathrm{E}, 660 \mathrm{~m}\right)$ (Crohn and Moore, 1984; Currie et al., 1992; Gain et al., 2019; Woodhead and Hergt, 2005). The carbonatite has a crystallization age of $731.0 \pm 0.2 \mathrm{Myr}$ (Gain et al., 2019); protracted cooling or a later thermal overprint during the $\mathrm{Al}$ ice Springs Orogeny (450-300 Myr) is indicated by $\mathrm{Pb}$ loss from some zircons (Gain et al., 2019). The emplacement occurred at temperatures $\leq 650{ }^{\circ} \mathrm{C}$, in a fluorine-rich environment (Currie et al., 1992). Zircons from this location have a median Hf concentration of $1.18 \%$ (first quartile $0.91 \%$, third quartile $1.19 \%$; Woodhead and Hergt, 2005). The two carbonatite bodies that constitute this occurrence rise about $10 \mathrm{~m}$ above the surrounding low-gradient landscape (Aus- 


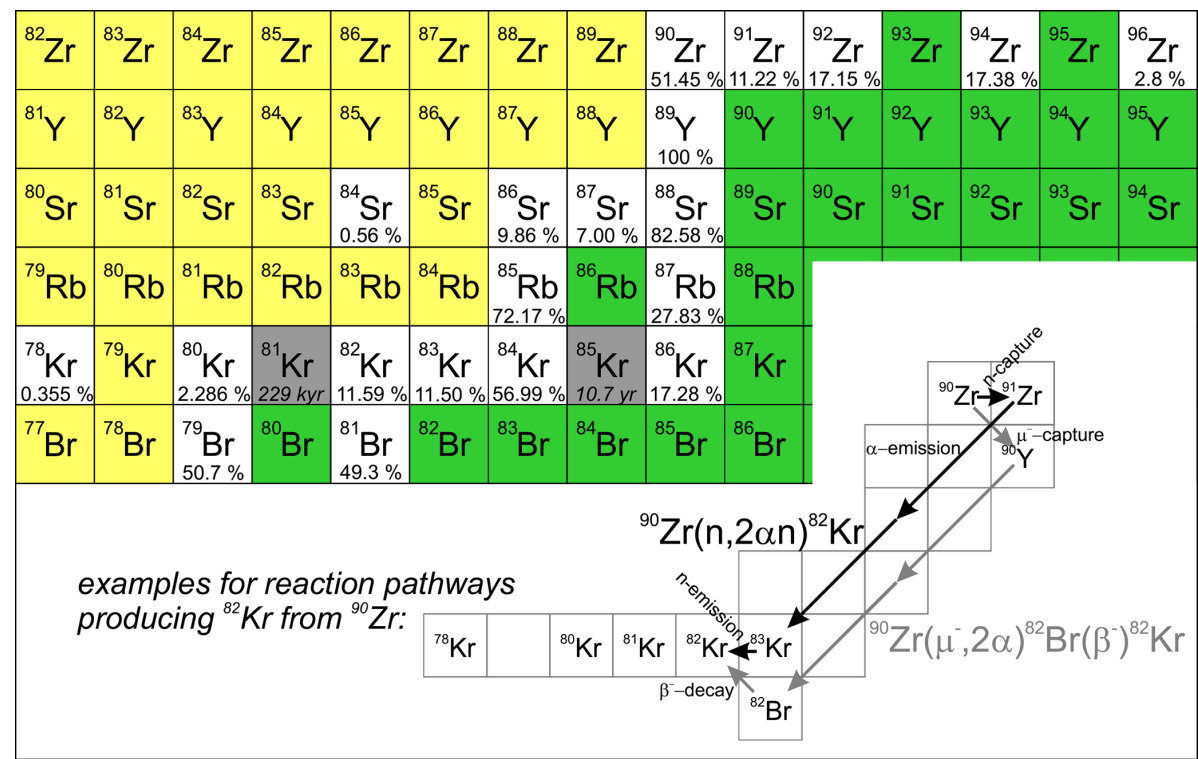

Figure 2. Excerpt of the nuclide chart of the region relevant for spallogenic and muogenic production of cosmogenic Krypton from its main target elements (Rb, Sr, Y and Zr; Gilabert et al., 2002; Marti, 1967). Stable isotopes (and isotopes with half-lives $>1$ Gyr; white) are shown with their natural abundance (in \%; Soppera et al., 2014). The long-lived nuclides ${ }^{81} \mathrm{Kr}$ and ${ }^{85} \mathrm{Kr}$ nuclides (i.e. half-lives $>1$ year, grey) are shown with their half-lives (Soppera et al., 2014). Nuclides to the left of the field of stable nuclides (yellow) decay via $\beta^{+}$(positron) emission or electron capture; nuclides to the right of the stable nuclides (green) decay via $\beta^{-}$(electron) emission from their nuclei. For illustration of how to "read" the chart for nuclear reactions, examples for reactions producing ${ }^{82} \mathrm{Kr}$ from ${ }^{90} \mathrm{Zr}$ are shown at the bottom of the figure.

tralian Vermiculite Industries, 2013). The elevation of possible sampling locations is $660 \pm 5 \mathrm{~m}$.

The material used in this study was obtained commercially via a private vendor, as part of two $1 \mathrm{~kg}$ batches of zircon sourced from an estate. The zircons were collected in the 1980s, when zircons were still abundant at the surface, prior to the Mud Tank becoming a well-frequented mineral collection site ("fossicking area"; Australian Vermiculite Industries, 2013). The zircons are sub-rounded; some show percussion marks from fluvial transport and fractured surfaces show signs of subsequent abrasion (Fig. 3). Most have a lighter colour than excavated zircons from the same site (the latter purchased from Dehne McLauchlin, Tasmania, Australia), suggesting bleaching from extended periods of exposure to sunlight (Gain et al., 2019). We assume that the zircons analysed were predominantly sampled from the surface. Individual zircons were crushed using a diamond mortar and subsequently sieved.

\subsection{SING}

These samples are from the Singida kimberlite field, Tanzania (Mannard, 1962). The samples were obtained commercially (Mawingu Gems, Idar Oberstein, Germany). At least 54 diatremes (Mannard, 1962) occur in an area of about $1900 \mathrm{~km}^{2}$ centred around $4^{\circ} 57^{\prime} \mathrm{S}, 34^{\circ} 25^{\prime} \mathrm{E}$. The zirconbearing kimberlites intruded into the Cretaceous African surface (Mannard, 1962; King, 1978) during the Eocene (Harri- son et al., 2001) at an altitude ranging from 1100 to $1500 \mathrm{~m}$ (Harrison et al., 2001). We adopt an elevation of $1300 \mathrm{~m}$ for scaling, when comparing the results from Singida with other locations. The U-Pb ages of all $(n=9)$ but one of the zircons used in this study are, within their individual uncertainties, identical to their mean age of $44.8 \pm 0.2 \mathrm{Myr}( \pm 1 \mathrm{SD}$; Table 2). One sample (SING-21) gives an age of $40.5 \pm 0.8 \mathrm{Myr}$ $( \pm 1 \mathrm{SD}$; Table 2$)$. Remnants of the original tuff rings are sometimes preserved (Harrison et al., 2001; Mannard, 1962) so the long-term erosion rates are presumably low. Much of the area is capped by relict calcretes and silcretes (Mannard, 1962). The area is covered by dry, deciduous woodland, currently receiving $520 \pm 260 \mathrm{~mm}$ annual rainfall (Harrison et al., 2001; Mannard, 1962). Zircons are concentrated in river sands near the pipes (Mannard, 1962), where they are mined in small pits down to several metres depth. We assume such a source for our samples.

The individual 5 to $10 \mathrm{~mm}$ sized crystals (Fig. 3) are of gem quality. Their outsides show surface roughing and small percussion marks from fluvial transport. Their Hf concentrations range between $0.6 \%$ and $1.1 \%$ (Table 2). Individual zircons were crushed using a diamond mortar and subsequently sieved.

\subsection{RBM, GOEL and VOGT}

These zircons stem from a kimberlitic diatreme near Ebersbrunn, Vogtland, Germany (Schmidt et al., 2013; Modalek 


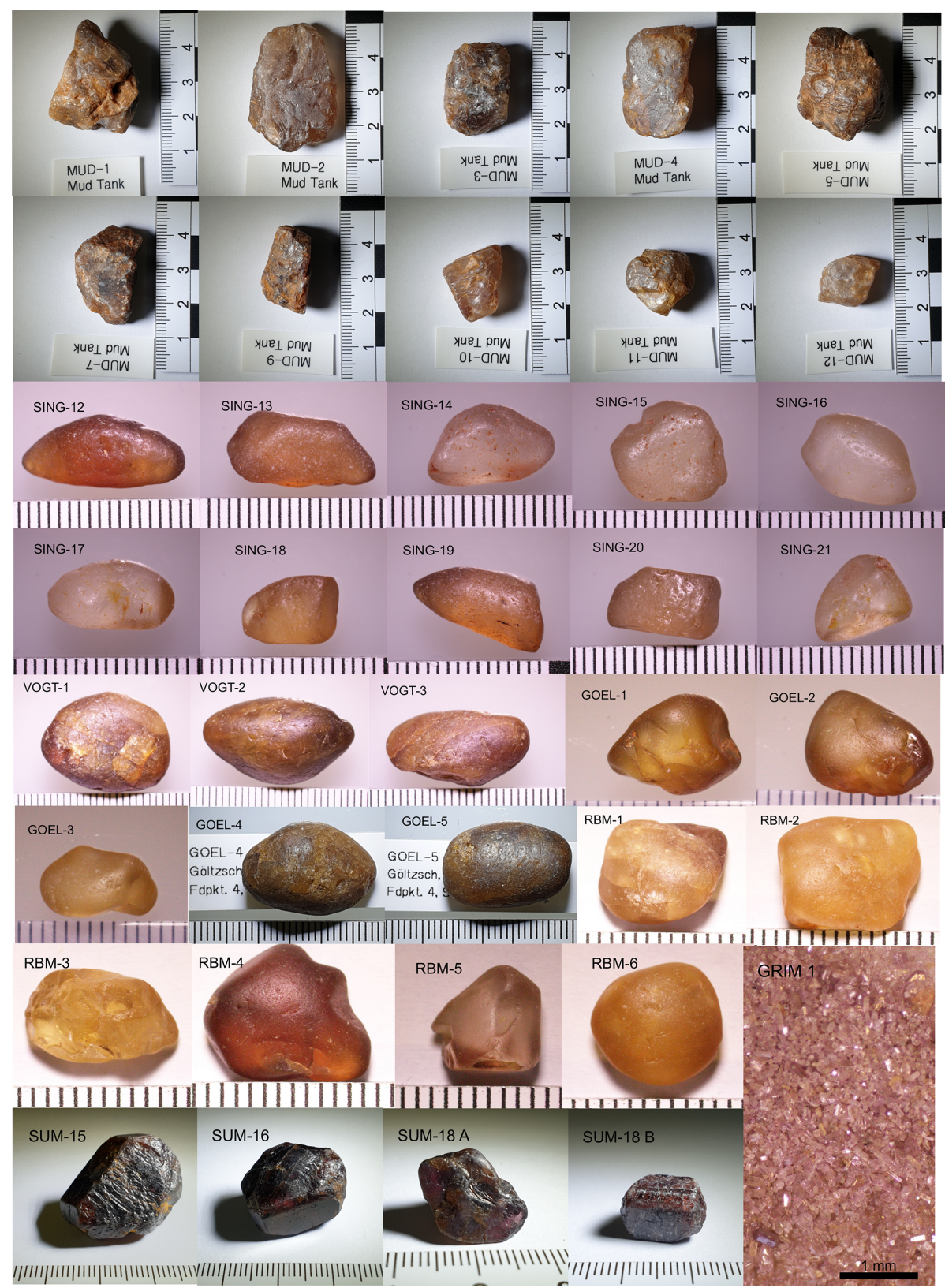

Figure 3. Photos of the zircons investigated. Scales are millimetres and centimetres. GRIM-1 is also exemplary for samples GRIM 19-1 and GRIM 19-2 (not shown). Crystals' weights are provided in Table 1 (where applicable).

et al., 2009). Ages of zircons from this location were determined as $71.1 \pm 0.8 \mathrm{Myr}(\mathrm{U}-\mathrm{Pb}$; Table 2$)$, which we take as the intrusion age. The diatreme is located on a topographic saddle (450 $\mathrm{m}$ elevation) in a soil-mantled landscape of moderate relief. The diatreme was first inferred through geophysical surveys and subsequently confirmed via shallow drill cores (Schmidt et al., 2013).

Zircons were obtained from local collectors, either commercially from a private vendor (VOGT) or provided in exchange (RBM, GOEL; from Sven Kreher, Goldmuseum Buchwald, Germany). They were extracted from modern stream- or river-bed sediments in the Göltzsch near Netschkau (VOGT; GOEL: $300 \mathrm{~m}, 50^{\circ} 37^{\prime} 25^{\prime \prime} \mathrm{N}$, $12^{\circ} 14^{\prime} 47^{\prime \prime} \mathrm{E}$ ) and its tributary Raumbach (RBM: $380 \mathrm{~m}$, $\left.50^{\circ} 37^{\prime} 0^{\prime \prime} \mathrm{N}, 12^{\circ} 21^{\prime} 24^{\prime \prime} \mathrm{E}\right)$. The headwaters of the latter originate in the diatreme. The sampling site for RBM zircons is $\sim 5 \mathrm{~km}$ downstream of the diatreme, those of VOGT and GOEL $\sim 15 \mathrm{~km}$. The smaller zircons $(5-10 \mathrm{~mm}$; all RBM and GOEL 1, 2 and 3) are mostly transparent; the pebblesized zircons are opaque to translucent (all VOGT and GOEL 4 and 5; Fig. 3). Individual zircons were crushed using a diamond mortar and subsequently sieved. 


\subsection{SUM}

These zircons are from the area around Sumbawanga, Tanzania $\left(1850 \mathrm{~m}, 7^{\circ} 58^{\prime} \mathrm{S}, 31^{\circ} 37^{\prime} \mathrm{E}\right)$. The samples were obtained commercially (Mawingu Gems, Idar Oberstein, Germany). Potential source rocks are Paleoproterozoic metamorphic rocks (Kabete et al., 2012). We adopt an elevation of $1850 \mathrm{~m}$ for scaling but the actual elevation of the source and/or finding location may be higher. The samples exhibit signs of fluvial transport such as edge-rounding and percussion marks (Fig. 3). We assume that these samples were retrieved from stream sediments or sedimentary deposits. The samples are from two different batches (SUM 18 A and B; the other SUM 15 and 16) and possibly stem from different locations. Individual zircons were crushed using a diamond mortar and subsequently sieved.

\subsection{GRIM}

These samples (GRIM 19-1; GRIM 19-2; GRIM-1) are from Nägelisgrätli, east of Grimsel Pass, Switzerland. The Nägelisgrätli is part of the transfluence pass through which the Last Glacial Maximum (LGM) Aare glacier was fed from the Rhône ice dome (Wirsig et al., 2016). ${ }^{10} \mathrm{Be}$ concentrations in quartz samples from the Nägelisgrätli are consistent with a single stage exposure history, with complete resetting of signals of prior exposure via glacial erosion (Wirsig et al., 2016). The Grimsel Granodiorite (part of the Central Aar Granite) has an intrusion age of $298 \pm 2 \mathrm{Ma}$ (Schaltegger and Corfu, 1992) and was subsequently affected by regional metamorphism during the Alpine orogenesis around 30-35 Myr ago (Hettmann et al., 2009).

Samples for the current study were taken at $2390 \mathrm{~m}$ (GRIM 19-1: $46^{\circ} 33^{\prime} 57.66^{\prime \prime} \mathrm{N}, 8^{\circ} 20^{\prime} 46.57^{\prime \prime} \mathrm{E}$; GRIM 192: $46^{\circ} 33^{\prime} 57.58^{\prime \prime} \mathrm{N}, 8^{\circ} 20^{\prime} 446.71^{\prime \prime} \mathrm{E}$ ) and $2478 \mathrm{~m}$ (GRIM-1: $46^{\circ} 34^{\prime} 13.9^{\prime \prime} \mathrm{N}, 8^{\circ} 21^{\prime} 6.4^{\prime \prime}$ E) elevation. GRIM-1 and GRIM 19-1 are bedrock samples (Fig. 4). GRIM 19-2 is a loose block in a shallow depression (Fig. 4) and was presumably ice-transported to this location, as all other means of transport, such as falling or rolling from uphill, can be excluded. The topography in the immediate vicinity of the sampling sites is favourable for accumulating significant snow cover (significant in terms of capability to reduce cosmogenic nuclide production). We performed no snow-cover corrections, since the main purpose of these samples is to cross-calibrate production rates of cosmogenic nuclides that are equally affected by snow cover; i.e. snow-cover effects cancel each other out. The same applies to topographic shielding corrections, which we likewise did not apply. Electro-pulse disaggregation of samples and subsequent zircon separation, by standard magnetic and heavy liquid techniques, was conducted by Zirchron LLC, Tucson, Arizona, USA. The zircon grains are $<125 \mu \mathrm{m}$ (Fig. 3).

\section{Methods}

\subsection{Krypton isotope determinations}

The general layout of the noble gas set-up at Cologne is described in Ritter et al. (2021), who focus on the analysis of cosmogenic neon. Here we reproduce some aspects of this description (Ritter et al., 2021), adding details that are pertinent for $\mathrm{Kr}$ extraction from zircon and cosmogenic $\mathrm{Kr}$ analysis.

\subsubsection{Krypton extraction from zircon}

Samples are placed into tantalum tubes $(4 \mathrm{~mm}$ outer diameter, ca. $12 \mathrm{~mm}$ long) that are pinched off at both ends. The tantalum tubes are placed into tungsten cups, which in turn are placed into a molybdenum sample revolver. For thermal insulation, several fragments $(250-500 \mu \mathrm{m})$ of zirconia (cubic stabilized zirconium oxide, melting point $\sim 2700^{\circ} \mathrm{C}$ ) are placed between the cups and revolver. Energy for the heat extraction in the vacuum is provided by an output-tuneable $600 \mathrm{~W}$ fibre laser (Rofin StarFiber600) at $1064 \mathrm{~nm}$ wavelength through galvanometer scanner optics (Rofin RS S 14 163/67 $0^{\circ}$ ), a UV-grade fused silica viewport (MDC Precision, 9722005) and a single-use fused-silica protective glass (Thorlabs, WG41050). The tantalum tubes are heated via scanning a continuous wave beam with $200 \mathrm{~W}$ power for a total of $5 \mathrm{~min}$. The scanning speed is $20 \mathrm{~cm} \mathrm{~s}^{-1}$, first rastering a rectangular area of 4 by $10 \mathrm{~mm}$ with a defocussed beam ( $\sim 0.5 \mathrm{~mm}$ diameter) for $3 \mathrm{~min}$, then with focussed beam a circular area with $5 \mathrm{~mm}$ diameter, on the then shrivelled tube, for $2 \mathrm{~min}$. The temperature achieved is sufficient to melt the top of the tantalum tube (melting point of tantalum is $3020 \pm 15^{\circ} \mathrm{C}$; Arblaster, 2018) and to quantitatively sublimate the silica content of zircon. Zircon melts incongruently above $\sim 1690^{\circ} \mathrm{C}$ (Kaiser et al., 2008), and the silica is presumably lost as silicon monoxide and oxygen (Fig. 5; Schick, 1960). Silicon monoxide is observed as a brown coating on the protection windows; the coating starts to appear within about $1 \mathrm{~min}$ after starting the laser extraction. The quantitative loss of silica is verified by weighing of the tantalum tubes after heat extraction; in most cases, the measured loss also indicates partial sublimation of $\mathrm{ZrO}_{2}$ (Fig. 6; Hoch et al., 1954).

\subsubsection{Krypton isotope determination}

Subsequent to the extraction, the evolved gases were cleaned by sequential exposure to two reactive metal getters (SAES NP50) and a stainless steel water trap (held at $205 \mathrm{~K}$ ). The noble gases are separated cryogenically on a stainless steel cold trap (Janis, twin coldhead model 204): neon and heavier noble gases are quantitatively condensed on the trap at $24 \mathrm{~K}$; the trap is then heated to $120 \mathrm{~K}$ and pumped (neon and argon are removed; $>99 \%$ of $\mathrm{Kr}$ remains on the trap); finally, the 


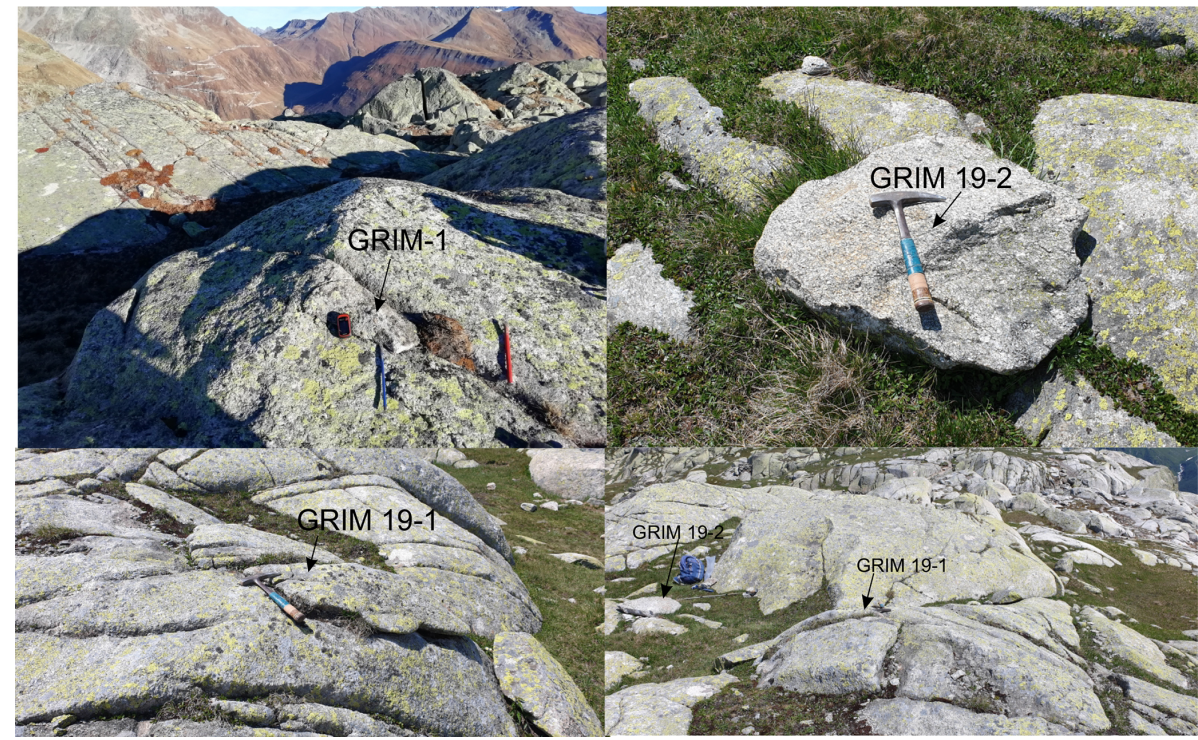

Figure 4. Samples and sampling locations on the Näglisgrätli, Grimsel Pass, Switzerland. Photo of GRIM 1 by Peter M. Abbott and Georgina King; all others by Tibor J. Dunai.

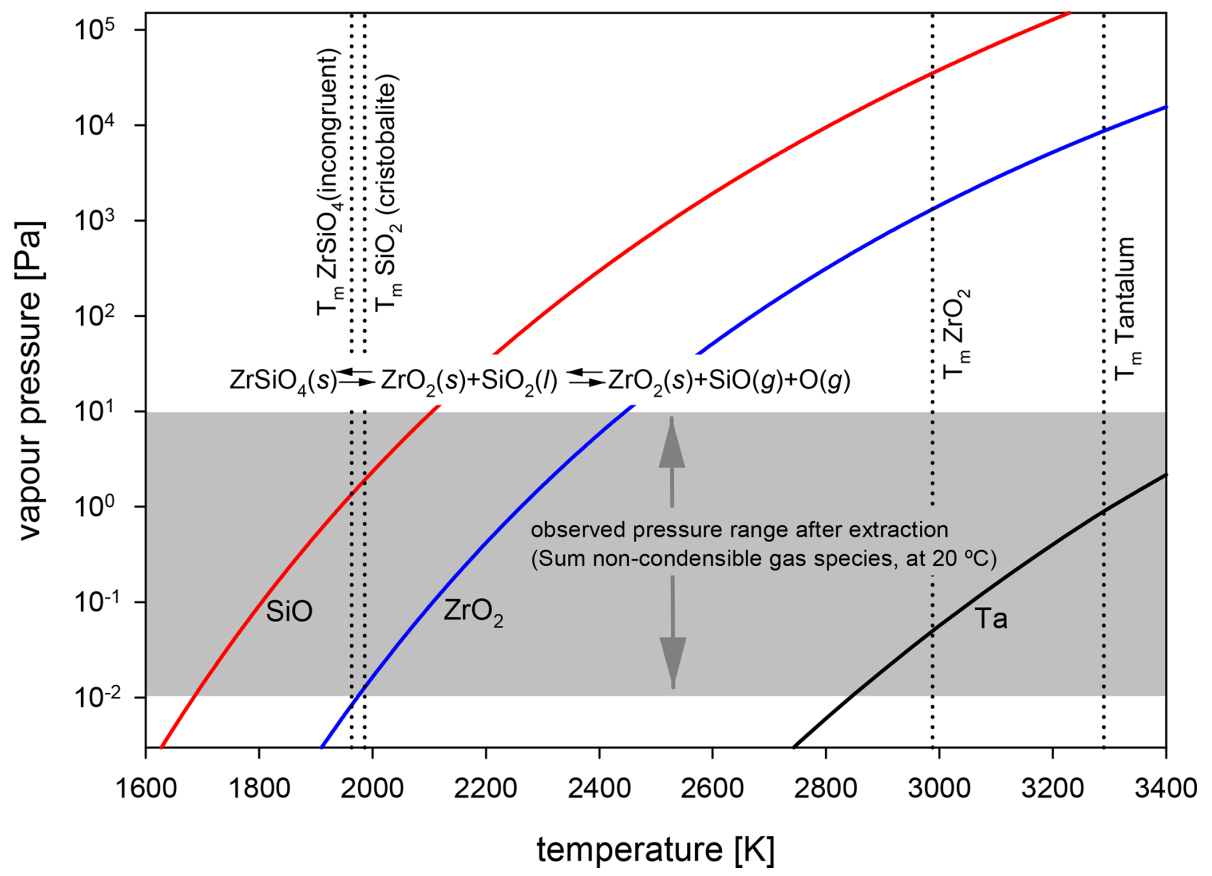

Figure 5. Vapour pressure of Silicon monoxide ( $\mathrm{SiO})$, zirconia $\left(\mathrm{ZrO}_{2}\right)$ and tantalum $(\mathrm{Ta})$ as a function of temperature (Schick, 1960; Hoch et al., 1954; Arblaster, 2018; Kaiser et al., 2008), and the melting points of zircon $\left(\mathrm{ZrSiO}_{4}\right)$, cristobalite $\left(\mathrm{SiO}_{2}\right)$ and zirconia (Kaiser et al., 2008). Zircon melts incongruently to $\mathrm{ZrO}_{2}$ and $\mathrm{SiO}_{2}$ melt (the melting temperature of the high-temperature modification of $\mathrm{SiO}{ }_{2}$, cristobalite, is only $\sim 10 \mathrm{~K}$ higher than that of zircon) (Kaiser et al., 2008). At a given temperature the vapour pressure of SiO is 1 to 2 orders of magnitude higher than that of $\mathrm{ZrO}_{2}$; the larger differences are at lower temperatures. Above the melting point of cristobalite, SiO can boil off, rather than sublimate from the surface of a solid (as is the case for $\mathrm{ZrO}_{2}$, below its melting point), if the pressure in the extraction cell is lower than the vapour pressure. Observations of the residual pressure of non-condensible gases after extraction (at this time the laser furnace is still hot from the extraction, but the laser power is switched off) indicate that in our experimental set-up SiO may boil off at temperatures $>2100 \mathrm{~K}$. The higher vapour pressure and the ability to boil off from a liquid lead to a preferential loss of $\mathrm{SiO}$, as compared to $\mathrm{ZrO}_{2}$, from zircon at high temperatures. 


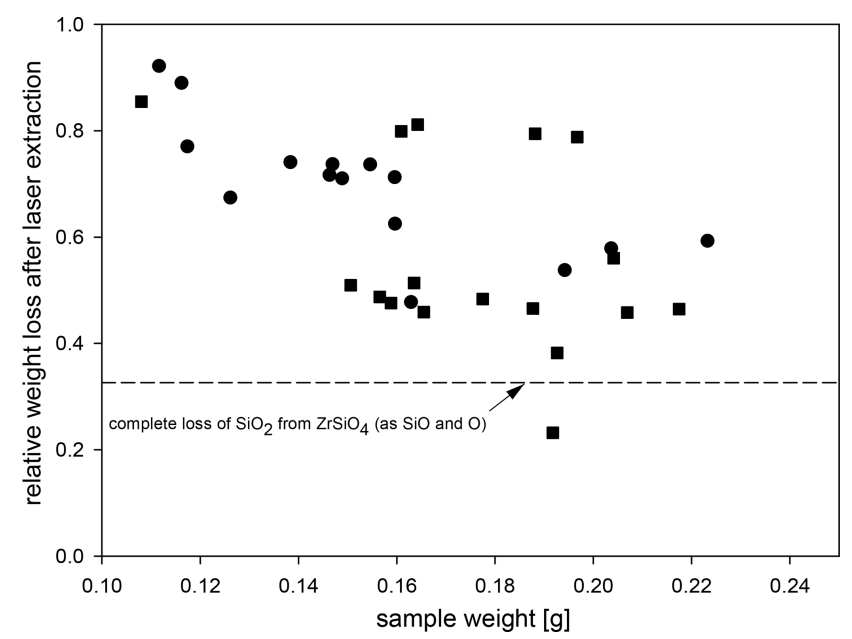

Figure 6. Relative mass loss of zircon samples after laser extraction as a function of initial sample weight. Squares denote samples with grain sizes above $125 \mu \mathrm{m}$; circles denote samples that (also) contain grains smaller $125 \mu \mathrm{m}$. All but one sample (RBM-6) have completely lost their constituent $\mathrm{SiO}_{2}$ and some of the $\mathrm{ZrO}_{2}$ residue (see also Fig. 5).

trap is heated to $240 \mathrm{~K}$ to release $\mathrm{Kr}$ for analysis in a noble gas mass spectrometer.

The noble gas mass spectrometer (Helix MCPlus, Thermo Fisher Scientific) is equipped with five combined Faraday multiplier (CFM) modules. One CFM module is fixed in axial position (Ax) and two movable CFM modules are each on the low (L1, L2) and the high (H1, H2) mass side of Ax. The L1 CFM module is flipped as compared to the factorystandard configuration (lateral positions of multiplier and Faraday slits are swapped). Four Faraday collectors are fitted with $10^{13} \Omega$ pre-amplification resistors (H1, Ax, L1, L2), one with $10^{12} \Omega(\mathrm{H} 2)$. The multipliers are operated in ioncounting mode. One CFM module (L1 position) has a higher resolution $(0.3 \mathrm{~mm}$ entry slit), the others have regular resolution $(0.6 \mathrm{~mm}$ slits $)$. At the operation conditions we used for krypton analysis (source slit $0.25 \mathrm{~mm} ; 10 \mathrm{KV}$ acceleration voltage), mass resolution (at $5 \%$ peak valley) and mass resolving power (between $10 \%$ and $90 \%$ of peak) on the L1 detector with $0.3 \mathrm{~mm}$ collector slit width are $\sim 1700$ and $\sim 6500$, respectively. For the detectors with $0.6 \mathrm{~mm}$ collector slit, the corresponding values are $\sim 1000$ and $\sim 6000$, respectively. This resolution allows the full separation of krypton isotopes from hydrocarbon isobars $(\sim 600$ is required; Burnard et al., 2013). The resolution of the L1 detector achieves separation of ${ }^{40} \mathrm{Ar}_{2} \mathrm{H}^{+}$from ${ }^{81} \mathrm{Kr}^{+}$at the ${ }^{81} \mathrm{Kr}^{+}$peak centre. Partial resolution is achieved on the remaining detectors, permitting interference-free $\left({ }^{40} \mathrm{Ar}_{2} \mathrm{H}^{+}\right)$analysis of ${ }^{81} \mathrm{Kr}^{+}$in an off-centre position. Interference of ${ }^{80} \mathrm{KrH}^{+}$on ${ }^{81} \mathrm{Kr}^{+}$cannot be resolved; we determine the ${ }^{84} \mathrm{KrH}^{+} /{ }^{84} \mathrm{Kr}^{+}$ ratio during calibration gas measurements (observed range $2-5 \times 10^{-6} ; n=26$ ) as a proxy for the ${ }^{80} \mathrm{KrH}^{+} /{ }^{80} \mathrm{Kr}^{+}$ratio and correct sample signals accordingly. Likewise, the interference from ${ }^{81} \mathrm{Br}^{+}$cannot be resolved, and we corrected it via monitoring and subtracting the background at the position of ${ }^{81} \mathrm{Kr}^{+}$during blank measurements. This background was found to be stable at the equivalent of $2200 \pm 200 \quad(n=7$; $1 \mathrm{SD})$ atoms ${ }^{81} \mathrm{Kr}$. Using multiples $(m)$ of the blank value $(2200 \pm 200$ atoms $)$, we estimate the detection limit for ${ }^{81} \mathrm{Kr}$ with the current set-up is $\sim 7000$ atoms $(m=3)$. Blanks yield $0.65 \pm 0.30$ attomol ${ }^{84} \mathrm{Kr}(n=8)$. Measurements of hot blanks at $0.75 \pm 0.25$ attomol ${ }^{84} \mathrm{Kr}$ (hot laser extraction, $n=$ $5,1 \mathrm{SD}$ of mean), cold blanks at $0.55 \pm 0.05$ attomol ${ }^{84} \mathrm{Kr}$ (same volume, but laser power off, $n=2,1 \mathrm{SD}$ of mean), or the line blank at $0.5 \pm 0.1$ attomol ${ }^{84} \mathrm{Kr}$ (purification line only, without the laser extraction volume, $n=1,1 \mathrm{SD}$ of measurement) are indistinguishable from each other. The observed Kr blanks are about 4-times lower than the lowest reported previously (Zimmermann et al., 2018).

We analysed the krypton isotopic abundances in multicollection mode. First, masses 78 to 85 are measured in four cycles on the multipliers - first: ${ }^{84} \mathrm{Kr}(\mathrm{H} 2),{ }^{83} \mathrm{Kr}(\mathrm{H} 1)$, ${ }^{81} \mathrm{Kr}(\mathrm{Ax}),{ }^{80} \mathrm{Kr}(\mathrm{L} 1),{ }^{78} \mathrm{Kr}(\mathrm{L} 2)$; second: ${ }^{83} \mathrm{Kr}(\mathrm{H} 2),{ }^{82} \mathrm{Kr}(\mathrm{H} 1)$; third: ${ }^{82} \mathrm{Kr}(\mathrm{Ax}),{ }^{81} \mathrm{Kr}(\mathrm{L} 1)$; fourth: ${ }^{84} \mathrm{KrH}^{+}(\mathrm{H} 2),{ }^{84} \mathrm{Kr}(\mathrm{H} 1)$, followed by sequential analysis of masses $86,84,83$ and 82 on the axial Faraday cup. Gain calibrations of multipliers are performed relative to the $\mathrm{H} 1$ multiplier, using the measurements of calibration gas (air pipette, containing $11.25 \pm 0.01 \mathrm{fmol} \mathrm{Kr}$ ) and the isotopic composition of air (Aregbe et al., 1996). The gain of the H1 multiplier is in turn calibrated to the axial Faraday collector using the corresponding ${ }^{84} \mathrm{Kr}^{+}$readings of calibration gas measurements. Within each of the two measurement periods, the variability of ${ }^{84} \mathrm{Kr}$ Faraday signals for calibration gas were smaller than $\pm 1 \%$ ( $1 \mathrm{SD}, n=26)$. Between the two periods the ion source was switched off, and after turning the source back on the sensitivity had dropped by $4 \%$. Calibration gas was measured prior to a set of two or three sample measurements on a given day, with these preceding calibrations used for gain calibration and interference correction $\left({ }^{80} \mathrm{KrH}^{+}\right)$of the subsequent samples. We use both determinations of ${ }^{81} \mathrm{Kr}$, on Ax (off-centre) and on L1, to obtain an error-weighted mean of intensities. We calculate the concentration of ${ }^{78} \mathrm{Kr}_{\text {it }}$ from the measured ${ }^{78} \mathrm{Kr} /{ }^{82} \mathrm{Kr}$ ratio, assuming that all ${ }^{82} \mathrm{Kr}$ is atmospheric. The ${ }^{81} \mathrm{Kr}_{\text {it }}$ concentration is corrected for interferences $\left({ }^{81} \mathrm{Br}^{+},{ }^{80} \mathrm{KrH}^{+}\right)$.

\section{2 ${ }^{10}$ Be determination}

Samples were ground and sieved to $250-1000 \mu \mathrm{m}$ and subsequently purified through sequential leaching with dilute hydrofluoric acid (Kohl and Nishiizumi, 1992). ICP-OES was used to verify the purity of the quartz before dissolution. ${ }^{10} \mathrm{Be}$ AMS (accelerator mass spectrometry) targets were prepared using the stacked-column approach (Binnie et al., 2015). A reagent blank and in-house quartz reference material (CoQtz$\mathrm{N}$; Binnie et al., 2019) was prepared in tandem with the sam- 
ples. AMS measurements were made on CologneAMS (Dewald et al., 2013), normalized to the ICN standard dilutions prepared by Nishiizumi for ${ }^{10} \mathrm{Be}$ (Nishiizumi et al., 2007). Concentrations of ${ }^{10} \mathrm{Be}$ are reported following blank subtractions, which were less than $1 \%$ of the total number of nuclides measured. The 1 standard deviation analytical precision of the nuclide concentrations was estimated by summing in quadrature the relative uncertainties on the AMS measurements, both the samples and the blank, along with a $1 \%$ (1 SD) estimate for the precision of the mass of ${ }^{9} \mathrm{Be}$ added during spiking. Concentrations obtained from intercomparison material (CoQtz-N; Binnie et al., 2019) measured alongside the samples are consistent with the long-term arithmetic mean $2.43 \pm 0.11 \times 10^{6}$ atoms $^{-1} \mathrm{CoQtz}(1 \mathrm{SD} ; N=55)$ at our laboratory.

\subsection{U-Pb-age determination}

$\mathrm{U}$, Th and $\mathrm{Pb}$ isotopes of zircon were performed by LAICPMS at FIERCE (Frankfurt Element and Isotope Research Center), Goethe University Frankfurt, following the methods described in Gerdes and Zeh (2009). A Thermo Scientific Element XR sector field ICP-MS was coupled to a RESOlution $193 \mathrm{~nm}$ ArF Excimer laser (COMPex Pro 102, Coherent) equipped with an S-155 two-volume ablation cell (Laurin Technic, Australia). The GJ-1 zircon (603 $\pm 1 \mathrm{Myr}$ ) was used as primary zircon reference material (RM) and RMs BB-16, Plešovice and Monastery zircon for validation of the analytical results. The results obtained on these zircon RMs were within $0.8 \%$ or better of the reported ages. Data processing (including common lead correction) was performed using an Isoplot-supported (Ludwig, 2012) Microsoft Excel-based spreadsheet (Gerdes and Zeh, 2009). Uncertainties reported are at the 2 SD level (i.e. $95 \%$ confidence) and are calculated by quadratic addition of the internal uncertainties (SE), counting statistics, gas-background uncertainties, common $\mathrm{Pb}$ corrections and the excess of scatter derived from the primary RM.

\section{Results}

The results of the $\mathrm{Kr}$ isotope determinations, U-Pb age determinations and the ${ }^{10} \mathrm{Be}$ results are provided in Tables 1,2 and 3 , respectively.

\subsection{Proof of concept for in situ-produced terrestrial krypton}

We find that all zircons analysed have ${ }^{78} \mathrm{Kr} /{ }^{82} \mathrm{Kr}$ and/or ${ }^{80} \mathrm{Kr} /{ }^{82} \mathrm{Kr}$ ratios that are distinct from air (Fig. 7).

Most of the data fall on the air-cosmogenic mixing line with no apparent influence from mass fractionation or nucleogenic Kr (Fig. 7). Neither mass fractionation nor the addition of nucleogenic ${ }^{80} \mathrm{Kr}$ and/or ${ }^{82} \mathrm{Kr}$ can produce the main trend (Fig. 7). However, either process may account for samples deviating from the mixing line. Furthermore, all zircons contain quantifiable amounts of ${ }^{81} \mathrm{Kr}$ (Fig. 8) that, in the absence of alternative sources, must be cosmogenic. Both observations, the mixing array and the presence of ${ }^{81} \mathrm{Kr}$, demonstrate the feasibility of measuring $\mathrm{Kr}_{\mathrm{it}}$ in terrestrial material.

Mass fractionation of noble gases is a common feature for samples originating from degassing magmatic systems (Kaneoka, 1980). Samples may contain residual gas from diffusive loss (enriched in heavy isotopes), or trapped gas that was fractionated during diffusion from minerals and/or degassing from melts (enriched in light isotopes). The resulting mass fractionation causes samples to plot along a path that deviates from the spallation line (Fig. 7). The samples that lie above the spallation line and to the left of the mass fractionation line (two from Mud Tank, one each from Singida and Vogtland) must contain some nucleogenic $\mathrm{Kr}$, requiring bromine in the host rocks, their sources and/or the samples themselves. Structurally there is no suitable site for bromine in the zircon lattice, so if present it is trapped in fluid or melt inclusions. Sources for kimberlites appear to be rich in halogens and in bromine (Kamenetsky et al., 2014; Burgess et al., 2009), which could explain the presence of nucleogenic $\mathrm{Kr}$ in some Singida and Vogtland zircons. The original melt, or source, of the Mud Tank carbonatite was rich in halogens (Currie et al., 1992), presumably containing sufficient bromine to give rise to significant nucleogenic Kr. Fractionation and the presence of nucleogenic $\mathrm{Kr}$ are interesting on their own account; to our knowledge natural nucleogenic $\mathrm{Kr}$ has not been reported before. However, for the purpose of the present study, we limit the use of the Krypton triple-isotope plot (Fig. 7) to discern samples with a simple $\mathrm{Kr}_{\text {atm }}$ and $\mathrm{Kr}_{\text {it }}$ mixture from those with complex components.

\subsection{Production ratios of terrestrial cosmogenic krypton isotopes}

In detail, the atmospheric-spallogenic mixing trend in ${ }^{78} \mathrm{Kr} /{ }^{82} \mathrm{Kr}$ vs. ${ }^{80} \mathrm{Kr} /{ }^{82} \mathrm{Kr}$ space (Fig. 7) that is defined by our results is slightly steeper than the one inferred from the proton-irradiation experiments (Gilabert et al., 2002) (zircon data: $1.682 \pm 0.015$ (1 SD) vs. proton-irradiation $\geq$ $49.2 \mathrm{~g} \mathrm{~cm}^{-2}$ shielding: $1.592 \pm 0.020$ (1 SD); Fig. 7). Hence, the ${ }^{78} \mathrm{Kr} /{ }^{82} \mathrm{Kr}$ and $/$ or ${ }^{80} \mathrm{Kr} /{ }^{82} \mathrm{Kr}$ production ratios appear to be different by $\sim 4 \%$ in the zircons as compared to the irradiation experiment. This small difference is unsurprising considering that in the proton-irradiation experiments the $1600 \mathrm{MeV}$ primary proton beam, as well as secondary protons and neutrons, produce $\mathrm{Kr}$ isotopes in roughly similar proportions (Gilabert et al., 2002), whereas near the Earth surface secondary neutrons dominate $(\sim 90 \%$ at sea level (Dunai, 2010)). We take the good agreement as indication that in the mass range of ${ }^{78} \mathrm{Kr}$ to ${ }^{82} \mathrm{Kr}$ the isotopic production ratios derived from proton-irradiation experiments (Gilabert 
Table 1. The analytical uncertainties of the isotope ratios and abundances are $1 \mathrm{SD}$; they are provided in brackets as last significant digits.

${ }^{78} \mathrm{Kr}_{\mathrm{cos}}$ is calculated from the difference between the measured and the atmospheric ${ }^{78} \mathrm{Kr} /{ }^{82} \mathrm{Kr}$ ratio (Aregbe et al., 1996); n.a.: not applicable.

\begin{tabular}{|c|c|c|c|c|c|c|c|c|c|c|}
\hline Sample ID & $\begin{array}{r}\text { Weight } \\
\text { crystal } \\
{[\mathrm{g}]}\end{array}$ & $\begin{array}{c}\text { Grain } \\
\text { size* } \\
{[\mu \mathrm{m}]}\end{array}$ & $\begin{array}{r}\text { Weight } \\
\text { analysed } \\
{[\mathrm{mg}]}\end{array}$ & ${ }^{84} \mathrm{Kr} /{ }^{82} \mathrm{Kr}$ & ${ }^{83} \mathrm{Kr} /{ }^{82} \mathrm{Kr}$ & ${ }^{80} \mathrm{Kr} /{ }^{82} \mathrm{Kr}$ & ${ }^{78} \mathrm{Kr} /{ }^{82} \mathrm{Kr}$ & $\begin{array}{r}{ }^{82} \mathrm{Kr} \\
{\left[10^{8} \mathrm{~g}^{-1}\right]}\end{array}$ & $\begin{array}{r}{ }^{81} \mathrm{Kr} \\
{\left[10^{6} \mathrm{~g}^{-1}\right]}\end{array}$ & $\begin{array}{r}{ }^{78} \mathrm{Kr}_{\mathrm{cos}} \\
{\left[10^{6} \mathrm{~g}^{-1}\right]}\end{array}$ \\
\hline SING-12 & 1.42 & $75-250$ & 162.9 & $4.475(19)$ & $0.9855(39)$ & $0.2124(10)$ & $0.04087(28)$ & $5.89(7)$ & $1.03(3)$ & $6.04(18)$ \\
\hline SING-13 & 1.40 & $75-250$ & 133.8 & $4.269(15)$ & $0.9974(28)$ & $0.2315(11)$ & $0.04997(45)$ & $6.41(8)$ & $3.62(6)$ & $12.4(3)$ \\
\hline SING 14 & 1.21 & $75-250$ & 116.2 & $4.496(13)$ & $0.9825(22)$ & $0.2400(12)$ & $0.04126(41)$ & $8.58(11)$ & $2.69(6)$ & $9.13(37)$ \\
\hline SING-15 & 1.44 & $75-250$ & 138.4 & $4.051(18)$ & $0.9942(40)$ & $0.2348(12)$ & $0.05607(37)$ & $5.04(5)$ & $2.83(4)$ & $12.8(2)$ \\
\hline SING-16 & 1.19 & $75-250$ & 111.6 & $3.952(14)$ & $0.9733(26)$ & $0.2373(13)$ & $0.05640(42)$ & $6.00(7)$ & $0.626(41)$ & $15.5(3)$ \\
\hline SING-17 & 1.31 & $75-250$ & 146.3 & $4.357(21)$ & $0.9813(41)$ & $0.2117(11)$ & $0.04326(35)$ & $5.35(5)$ & 2.12(4) & $6.75(2)$ \\
\hline SING-18 & 0.91 & $75-250$ & 126.2 & $4.415(24)$ & $0.9767(50)$ & $0.2113(14)$ & $0.04079(45)$ & $4.18(7)$ & $0.152(30)$ & $4.26(2)$ \\
\hline SING-19 & 1.37 & $75-250$ & 159.7 & $4.209(15)$ & $0.9914(30)$ & $0.2253(13)$ & $0.05046(45)$ & $3.75(5)$ & $2.27(4)$ & $7.44(2)$ \\
\hline SING-20 & 1.35 & $75-250$ & 159.6 & $4.335(22)$ & $0.9830(49)$ & $0.2166(13)$ & $0.04470(53)$ & $3.65(5)$ & $0.154(26)$ & $5.14(2)$ \\
\hline SING-21 & 1.01 & $75-250$ & 117.4 & $4.538(24)$ & $0.9593(49)$ & $0.1916(14)$ & $0.03180(32)$ & $6.33(8)$ & $0.390(26)$ & $0.75(2)$ \\
\hline VOGT-1 & 7.75 & $125-250$ & 199.8 & $3.903(27)$ & $0.9826(65)$ & $0.2377(19)$ & $0.05671(48)$ & $2.50(3)$ & $0.267(19)$ & $6.51(15)$ \\
\hline VOGT-2 & 7.43 & $125-250$ & 192.7 & $3.216(12)$ & $1.0755(38)$ & $0.3156(18)$ & $0.09928(67)$ & $2.78(5)$ & $0.215(20)$ & 19.1(4) \\
\hline VOGT-3 & 4.49 & $125-250$ & 156.5 & $3.561(13)$ & $1.0688(32)$ & $0.2964(14)$ & $0.08662(53)$ & $3.93(5)$ & $0.271(22)$ & $22.0(4)$ \\
\hline GOEL-1 & 1.33 & $125-250$ & 165.5 & $3.460(19)$ & $1.0501(55)$ & $0.2947(19)$ & $0.08625(65)$ & $3.85(6)$ & $0.246(25)$ & 21.4(4) \\
\hline GOEL-2 & 1.60 & $125-250$ & 160.9 & $4.189(18)$ & $1.0030(41)$ & $0.2360(13)$ & $0.05380(62)$ & $3.84(5)$ & $0.205(27)$ & $8.90(26)$ \\
\hline GOEL-3 & 0.62 & $125-250$ & 108.0 & $4.317(36)$ & $0.9880(16)$ & $0.2824(19)$ & $0.04749(59)$ & $9.54(14)$ & $0.483(46)$ & 16.1(6) \\
\hline GOEL-4 & 8.11 & $125-250$ & 214.5 & $4.047(17)$ & $1.0178(40)$ & $0.2437(12)$ & $0.06067(58)$ & $2.88(1)$ & $0.270(21)$ & $8.67(2)$ \\
\hline GOEL-5 & 7.56 & $125-250$ & 211.1 & $4.110(14)$ & $1.0137(28)$ & $0.2411(10)$ & $0.05815(33)$ & $4.38(6)$ & $0.244(18)$ & $12.0(2)$ \\
\hline RBM-1 & 1.23 & $125-250$ & 206.9 & $3.565(13)$ & $1.0237(27)$ & $0.2826(14)$ & $0.08023(47)$ & $4.57(6)$ & $0.438(20)$ & $22.7(4)$ \\
\hline RBM-2 & 1.86 & $125-250$ & 150.6 & $3.937(18)$ & $1.0016(42)$ & $0.2444(14)$ & $0.06005(42)$ & $4.22(4)$ & $0.329(22)$ & $12.4(2)$ \\
\hline RBM-3 & 0.90 & $125-250$ & 217.5 & $4.507(19)$ & $0.9723(38)$ & $0.2016(11)$ & $0.03545(37)$ & $2.77(3)$ & $0.521(17)$ & $1.34(1)$ \\
\hline RBM-4 & 1.32 & $125-250$ & 187.7 & $4.842(21)$ & $1.0651(44)$ & $0.2080(13)$ & $0.05148(38)$ & $3.49(5)$ & $0.430(25)$ & $7.29(17)$ \\
\hline RBM-5 & 0.72 & $125-250$ & 177.5 & $4.253(16)$ & $1.0071(33)$ & $0.2338(11)$ & $0.05189(31)$ & $5.56(8)$ & $0.423(22)$ & $11.8(2)$ \\
\hline RBM-6 & 1.04 & $125-250$ & 191.8 & $4.254(14)$ & $1.0103(30)$ & $0.2377(09)$ & $0.05343(27)$ & $8.20(9)$ & $0.386(17)$ & $18.7(3)$ \\
\hline MUD-1 & 25.4 & $125-250$ & 196.7 & $4.475(15)$ & $0.9652(30)$ & $0.2054(10)$ & $0.03532(24)$ & $2.87(4)$ & 1.65(3) & $1.35(7)$ \\
\hline MUD-2 & 22.6 & $125-250$ & 207.3 & $4.249(22)$ & $0.9734(47)$ & $0.2123(12)$ & $0.04371(33)$ & $3.12(3)$ & $1.53(2)$ & $4.09(11)$ \\
\hline MUD-3 & 16.4 & $125-250$ & 164.2 & $4.541(14)$ & $0.9705(28)$ & $0.2290(19)$ & $0.03461(19)$ & $3.64(5)$ & $1.45(3)$ & $1.45(7)$ \\
\hline MUD-4 & 25.7 & $125-250$ & 189.4 & $4.285(16)$ & $0.9805(31)$ & $0.2170(10)$ & $0.04347(42)$ & $3.36(4)$ & $2.38(4)$ & $4.32(15)$ \\
\hline MUD-6 & 30.9 & $125-250$ & 232.7 & $4.496(18)$ & $0.9851(37)$ & $0.2074(10)$ & $0.03903(28)$ & $3.47(4)$ & $1.57(2)$ & $2.92(1)$ \\
\hline MUD-7 & 17.6 & $125-250$ & 188.2 & $4.649(15)$ & $0.9895(29)$ & $0.2539(19)$ & $0.03595(59)$ & $4.85(6)$ & $1.81(4)$ & $2.58(29)$ \\
\hline MUD-9 & 13.0 & $125-250$ & 204.1 & $4.429(19)$ & $0.9797(35)$ & $0.2064(11)$ & $0.03866(40)$ & $3.36(4)$ & $2.13(4)$ & $2.70(14)$ \\
\hline MUD-10 & 9.68 & $125-250$ & 202.4 & $4.352(23)$ & $0.9804(49)$ & $0.2094(14)$ & $0.04131(32)$ & $3.22(3)$ & $2.22(3)$ & $3.44(11)$ \\
\hline MUD-11 & 11.0 & $125-250$ & 205.1 & $4.530(25)$ & $0.9728(53)$ & $0.1996(13)$ & $0.03438(28)$ & $2.66(3)$ & $1.37(2)$ & $1.00(7)$ \\
\hline MUD-12 & 8.00 & $125-250$ & 220.3 & $4.461(13)$ & $0.9856(27)$ & $0.2141(09)$ & $0.04014(25)$ & $4.50(6)$ & $1.83(3)$ & $4.28(13)$ \\
\hline SUM-15 & 20.9 & $125-250$ & 177.2 & $4.672(21)$ & $1.0477(45)$ & $0.2062(15)$ & $0.03903(36)$ & $2.75(4)$ & $1.16(3)$ & $2.31(10)$ \\
\hline SUM-16 & 16.2 & $125-250$ & 150.3 & $4.621(36)$ & $1.0479(78)$ & $0.2098(18)$ & $0.04049(59)$ & $2.96(4)$ & $2.12(4)$ & $2.93(18)$ \\
\hline SUM-18A & 3.08 & $125-250$ & 158.8 & $4.612(19)$ & $0.9816(37)$ & $0.1933(10)$ & $0.03242(47)$ & $3.81(5)$ & $1.48(4)$ & $0.68(18)$ \\
\hline SUM-18B & 2.42 & $125-250$ & 163.5 & $4.648(13)$ & $0.9910(21)$ & $0.2019(09)$ & $0.03313(31)$ & $4.87(5)$ & $0.528(23)$ & $1.22(15)$ \\
\hline GRIM-1 & n.a. & $<125$ & 223.3 & $5.110(28)$ & $1.1300(57)$ & $0.2025(14)$ & $0.03159(38)$ & $2.50(3)$ & $0.482(20)$ & $0.241(94)$ \\
\hline GRIM-19-1A & n.a. & $<125$ & 203.7 & $5.097(28)$ & $1.1121(59)$ & $0.1985(12)$ & $0.03158(25)$ & $3.26(4)$ & $0.445(19)$ & $0.313(81)$ \\
\hline GRIM-19-1B & n.a. & $<125$ & 194.2 & $5.011(26)$ & $1.0860(52)$ & $0.1975(13)$ & $0.03109(37)$ & $3.88(5)$ & $0.480(19)$ & $0.181(142)$ \\
\hline GRIM-19-1C & n.a. & $<125$ & 148.9 & $5.091(12)$ & $1.1084(23)$ & $0.2033(07)$ & $0.03177(31)$ & $3.29(4)$ & $0.462(27)$ & $0.378(104)$ \\
\hline GRIM-19-2A & n.a. & $<125$ & 154.6 & $5.053(23)$ & $1.0996(46)$ & $0.1975(12)$ & $0.03135(30)$ & $3.81(4)$ & $0.424(26)$ & $0.278(114)$ \\
\hline GRIM-19-2B & n.a. & $<125$ & 146.9 & $5.080(20)$ & $1.0980(42)$ & $0.2019(11)$ & $0.03141(20)$ & $4.07(5)$ & $0.415(26)$ & $0.320(81)$ \\
\hline
\end{tabular}

* Grain size after crushing and sieving. GRIM-19-1A, -1B and -1C are aliquots of sample GRIM-19-1; GRIM-19-2A and -2B are aliquots of sample GRIM-19-2.

et al., 2002) are a reasonable approximation for $\mathrm{Kr}$ produced by spallation on Zr near the Earth's surface.

\subsection{Cross-calibration of ${ }^{81} \mathrm{Kr}$ and ${ }^{10} \mathrm{Be}$ production rates}

In samples of glacially eroded rocks from the Grimsel Pass (Switzerland) we determined concentrations of both ${ }^{81} \mathrm{Kr}_{\text {it }}$ in zircon and ${ }^{10} \mathrm{Be}$ in quartz (Tables 1 and 3). The resulting ${ }^{81} \mathrm{Kr}_{\mathrm{it}}(\mathrm{zrc}) /{ }^{10} \mathrm{Be}$ (qtz) ratio is $1.545 \pm 0.045$ (1 SE, error weighted mean, $n=3$ ). Using a ${ }^{10} \mathrm{Be}$ production rate of $4.10 \pm 0.17$ atoms $\mathrm{g}^{-1} \mathrm{yr}^{-1}$ (1 SE; at sea level and high latitude (SLHL) for Europe, Martin et al., 2017; LSD scaling, Lifton et al., 2014, atmospheric pressure, Uppala et al., 2005), we derive a SLHL ${ }^{81} \mathrm{Kr}_{\text {it }}$ production rate of $6.33 \pm 0.32$ atoms $\mathrm{g}^{-1} \mathrm{yr}^{-1}(1 \mathrm{SD})$ in zircon.

\subsection{Histories of exposure and burial}

Due to decay of ${ }^{81} \mathrm{Kr}$, intermittent burial of samples lowers the measured ${ }^{81} \mathrm{Kr} /{ }^{78} \mathrm{Kr}_{\text {it }}$ ratio with respect to the pro- 


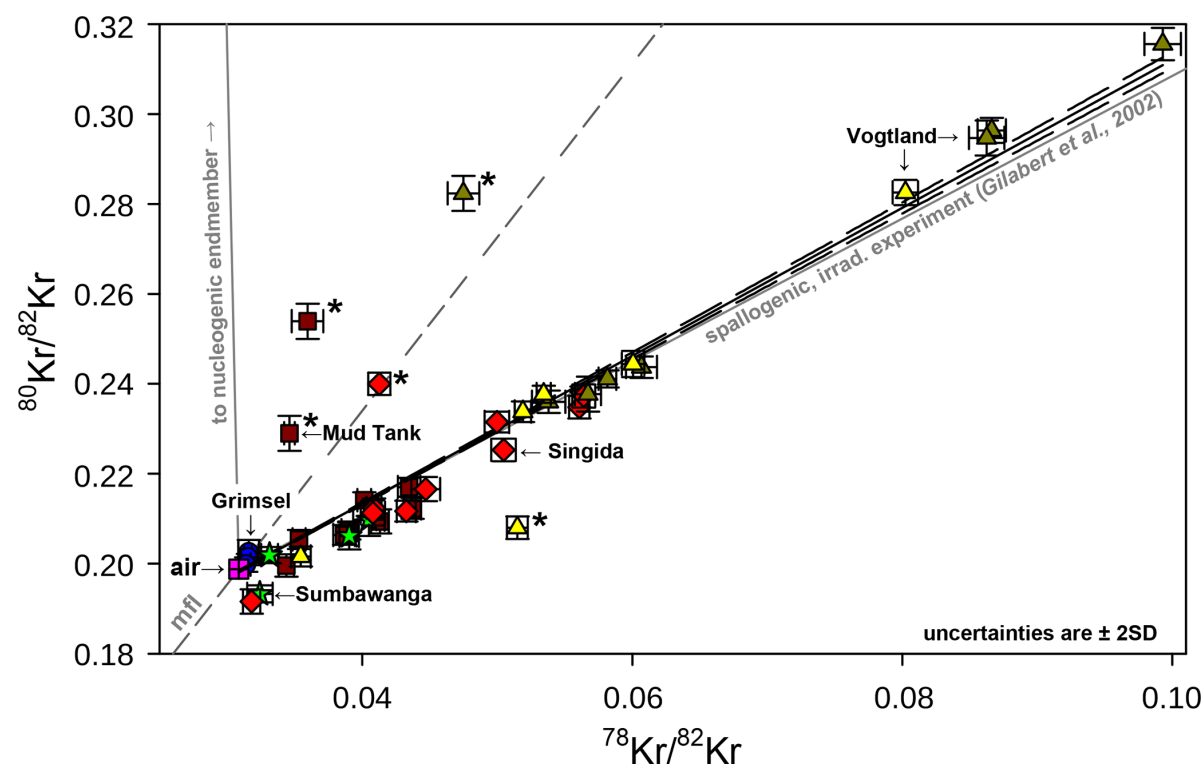

Figure 7. Identification of krypton components and of processes fractionating krypton isotopes. Kr data from zircons of various locations, all of which have been exposed to cosmic rays at or near the Earth's surface, form a linear trend between air (atmospheric Kr; Aregbe et al., 1996) and a spallogenic endmember. Several samples plot far from this trend (marked with an asterisk *). They may contain fractionated krypton ("mfl" mass-fractionation line; Kaneoka, 1980) and/or nucleogenic krypton. The linear least square regression of the data (performed with the regression module of SigmaPlot 14) is shown by the solid black line and excludes measurements marked with an asterisk *. The regression is forced through air. The black dashed lines are the $95 \%$ confidence intervals of the regression line. Regression of the Kr concentrations from the zircon samples indicates that the terrestrial cosmogenic endmember is slightly different to that obtained from proton-irradiation experiments (solid grey line; Gilabert et al., 2002). Brown squares are Mud Tank carbonatite; red diamonds are for the Singida kimberlite field; green stars are Sumbawanga; blue circles are the Grimsel pass region; triangles represent Vogtland (dark yellow: samples GOEL and VOGT; yellow: samples RBM).

Table 2. Laser ablation ICP-MS age determinations and Hf concentrations of zircons from Singida, Tanzania (samples "SING"), and Vogtland ("Göltsch (zr1-4)", mean age of four zircons from the same locality as samples "VOGT" and "GOEL"). The mean age of the samples from Singida is $44.80 \pm 0.24 \mathrm{Myr}$ ( $1 \mathrm{SD} ; n=9$; SIN21 excluded). Within their individual uncertainties, the individual ages of all zircons, bar SING-21, agree with this mean. The age of SING-21 is significantly ( $>3 \mathrm{SD}$ ) lower than this mean. The numbers in brackets denote the number of analyses from which the mean Hf concentration was calculated; n.d.: not determined.

\begin{tabular}{lrr}
\hline Sample ID & U-Pb age $[\mathrm{Myr}]$ & Hf $[\mathrm{ppm}]$ \\
\hline SING-12 & $45.14 \pm 1.08$ & $6980 \pm 130(n=6)$ \\
SING-13 & $45.14 \pm 1.07$ & $6870 \pm 160(n=7)$ \\
SING 14 & $44.86 \pm 1.23$ & $8760 \pm 150(n=7)$ \\
SING-15 & $44.86 \pm 1.38$ & $10200 \pm 230(n=6)$ \\
SING-16 & $44.83 \pm 1.17$ & $8010 \pm 150(n=6)$ \\
SING-17 & $44.36 \pm 1.27$ & $8650 \pm 120(n=6)$ \\
SING-18 & $44.70 \pm 0.35$ & $7870 \pm 140(n=6)$ \\
SING-19 & $44.80 \pm 0.31$ & $6410 \pm 94(n=6)$ \\
SING-20 & $44.51 \pm 0.34$ & $7960 \pm 100(n=6)$ \\
SING-21 & $40.47 \pm 0.42$ & $10810 \pm 160(n=7)$ \\
Göltzsch (zr1-4) & $71.2 \pm 0.8$ & n.d. \\
\hline
\end{tabular}

duction ratio; with increasing exposure time at the surface, the measured ${ }^{81} \mathrm{Kr} /{ }^{78} \mathrm{Kr}_{\text {it }}$ ratio decreases as ${ }^{81} \mathrm{Kr}$ tends towards saturation concentrations. Hence, samples with the highest ${ }^{81} \mathrm{Kr} /{ }^{78} \mathrm{Kr}_{\text {it }}$ ratio for a given ${ }^{81} \mathrm{Kr}$ concentration $\left({ }^{81} \mathrm{Kr}\right.$ concentration is a proxy for the duration of exposure; Fig. 8) may be used to constrain the ${ }^{81} \mathrm{Kr} /{ }^{78} \mathrm{Kr}_{\text {it }}$ production ratio. Using the two samples from Mud Tank with the highest ${ }^{81} \mathrm{Kr} /{ }^{78} \mathrm{Kr}_{\text {it }}$ ratio for exposures $>200 \mathrm{kyr}$ (MUD1 and MUD-11), we constrain the ${ }^{81} \mathrm{Kr} /{ }^{78} \mathrm{Kr}_{\text {it }}$ production ratio to be $1.94 \pm 0.09$ ( $1 \mathrm{SE}$; error weighted mean). The ${ }^{81} \mathrm{Kr} /{ }^{78} \mathrm{Kr}_{\text {it }}$ production ratio derived from proton-irradiation experiments is $\sim 15 \%$ higher (for $\geq 49.2 \mathrm{~g} \mathrm{~cm}^{-2}$ shielding, ${ }^{81} \mathrm{Kr} /{ }^{78} \mathrm{Kr}_{\mathrm{it}}=2.30 \pm 0.02,1 \mathrm{SD}$; Table 2a of Gilabert et al., 2002). This difference may be due to unaccounted-for episodes of sample burial, or the inherently different reaction pathways and energy spectra in proton experiments $(\mathrm{Gi}-$ labert et al., 2002) as compared to the secondary neutron flux at the Earth's surface (Lifton et al., 2014). Using either production ratio, the results for all Mud Tank zircons analysed are consistent with the ${ }^{81} \mathrm{Kr}_{\text {it }}$ production rate of $6.33 \pm 0.32$ atoms $\mathrm{g}^{-1} \mathrm{yr}^{-1}$ derived earlier and the ${ }^{81} \mathrm{Kr}$ halflife of $229 \pm 11 \mathrm{kyr}$ (Baglin, 2008), assuming either a continuous exposure, a uniform erosion rate or a complex exposure 
Table 3. ${ }^{10}$ Be results for quartz samples from the Grimsel Pass, Switzerland. GRIM-19-2a and GRIM-19-2b are duplicate measurements of sample GRIM-19-2. The uncertainties denote the standard deviation (1 SD). ${ }^{10}$ Be concentrations are reported after the chemistry blank correction. Samples with 24.03 to $28.33 \mathrm{~g}$ quartz were spiked with ca. $300 \mu \mathrm{g}$ Be using a commercial Beryllium ICP standard solution (Scharlau), with a concentration of $1000 \mathrm{mg} \mathrm{L}^{-1}$ traceable to NIST; n.a.: not applicable.

\begin{tabular}{lllrr}
\hline Sample & AMS ID & Lab ID & ${ }^{10} \mathrm{Be} /{ }^{9} \mathrm{Be}$ & $\begin{array}{r}10 \\
\mathrm{Be} \text { concentration } \\
{\left[10^{5} \text { atoms }^{-1}\right]}\end{array}$ \\
\hline GRIM-1 & s16545 & KL-1122B & $4.03 \pm 0.13 \times 10^{-13}$ & $3.21 \pm 0.11$ \\
GRIM-19-1 & s16546 & KL-1123B & $3.63 \pm 0.12 \times 10^{-13}$ & $3.07 \pm 0.11$ \\
GRIM-19-2a & s16547 & KL-1124B & $3.03 \pm 0.11 \times 10^{-13}$ & $2.44 \pm 0.09$ \\
GRIM-19-2b & s16548 & KL-1125B & $3.48 \pm 0.12 \times 10^{-13}$ & $2.48 \pm 0.09$ \\
Lab blank & s16550 & KL-B14B & $9.8 \pm 3.3 \times 10^{-16}$ & n.a. \\
\hline
\end{tabular}

history (Fig. 8). In the following we use the ${ }^{81} \mathrm{Kr} /{ }^{78} \mathrm{Kr}_{\text {it }}$ production ratio of $1.94 \pm 0.09$.

\subsubsection{Glacially exhumed samples}

The results of the glacially exhumed samples from the Grimsel Pass area are consistent with a post-LGM (Last Glacial Maximum) exposure under a variable and significant snow cover (Wirsig et al., 2016). Grimsel Pass ${ }^{81} \mathrm{Kr} /{ }^{78} \mathrm{Kr}_{\text {it }}$ values $(1.33 \pm 0.25,1.35 \pm 0.30$ and $2.00 \pm 0.79 ; 1 \mathrm{SE}$, error weighted mean; Fig. 8) are consistent with the production ratio derived from the Mud Tank zircons within two standard errors (1.94 $\pm 0.09 ; 1 \mathrm{SE}$; see above); however, two of three samples are inconsistent with the experimental value (Sect. 4.4; see above). Irrespective of eventual intermittent cover, samples with no exposure prior to glacial erosion history (as is inferred for Grimsel Pass area; see Sect. 2) should exhibit ${ }^{81} \mathrm{Kr} /{ }^{78} \mathrm{Kr}_{\text {it }}$ ratios indistinguishable from the production ratio. The $40 \%-50 \%$ difference between the expected ${ }^{81} \mathrm{Kr}_{\text {it }}$ concentrations at Grimsel Pass (commensurate to $\sim 13 \mathrm{kyr}$ exposure (Wirsig et al., 2016)) and those measured (Fig. 8) indicate a notable amount of seasonal snow cover at our sampling locations (Wirsig et al., 2016). The quartz-vein samples used by Wirsig et al. (2016) for exposure dating were collected on steep-sided outcrops to prevent significant snow cover; our granite samples were from nearhorizontal outcrops (Fig. 4) to ensure a simple exposure geometry of our large $(\sim 10 \mathrm{~kg}$; in order to recover sufficient zircon) and thick samples (10 to $15 \mathrm{~cm}$ ).

\subsubsection{Sedimentary samples}

The sedimentary zircon megacrysts from Australia, Tanzania and Germany have the ability to record their individual (paleo-)exhumation and subsequent burial histories. Their exhumation rate is taken to be representative of the erosion rates of their former host rocks (for simplicity we assume a $2.7 \mathrm{~g} \mathrm{~cm}^{-3}$ density for all, which may not necessarily be the case). The simplest case is for zircons from Mud Tank (Australia), since they were collected at or near the surface in close proximity to their source rock. The sample results indicate individual exhumation rates between 1 and $0.1 \mathrm{~m} \mathrm{Myr}$ ${ }^{-1}$ (Fig. 8) and that some zircons have had a complex exposure history, with intermittent burial and/or production at shallow depths (Fig. 8). These results are consistent with erosion rates obtained for other low-relief, post-orogenic landscapes in arid Central Australia (Struck et al., 2018b, a) and with being sampled at or near the surface of a thin sediment cover (Australian Vermiculite Industries, 2013; Struck et al., 2018a).

A more complex history is implied for the zircons from the Singida peneplain (Tanzania, Mannard, 1962). The sediments of the ephemeral rivers from which they were mined commonly have a thickness of several metres; thus, samples may record extended periods of burial. The samples from the Singida form a pattern $(n=9$; Fig. 8$)$ that is commensurate with exhumation rates lower than $0.1 \mathrm{~m} \mathrm{Myr}^{-1}$ and continuous exposure at the surface, or burial for to up to $1 \mathrm{Myr}$. These results from the Singida diatreme field are consistent with expectations for an arid, low-relief $(<50 \mathrm{~m})$, long wavelength (>10 km) landscape (Mannard, 1962; Harrison et al., 2001), notionally a relic of the Cretaceous age ("African Surface"; Mannard, 1962; King, 1978; Burke et al., 2008). The notion of long-term low erosion rates is supported by the partial preservation of tuff rings of Eocene diatremes (Mannard, 1962; Harrison et al., 2001), with the tuffs being the sourcerocks of the zircons (Mannard, 1962). The erosion rates we infer from the zircons are very low $\left(<0.1 \mathrm{~m} \mathrm{Myr}^{-1}\right)$ and appear to have been invariable during the last $1 \mathrm{Myr}$. Assuming these rates apply to even longer timescales, the source of the zircons would have eroded by less than $4.5 \mathrm{~m}$ since the eruption of the diatreme, $44.8 \pm 0.2 \mathrm{Myr}$ ago (mean $\mathrm{U}-\mathrm{Pb}$ ages of zircons; $n=9,1 \mathrm{SD}$; Table 2).

The basic framework for zircons from Sumbawanga (Tanzania) is similar to Singida inasmuch as the zircons were retrieved from river sediments but the surface process rates are different. The Precambrian source rocks (Kabete et al., 2012) for zircons from Sumbawanga have experienced postMid-Miocene uplift and tectonic segmentation as part of the Tanganyika-Rukwa-Malawi transform segment of the East 


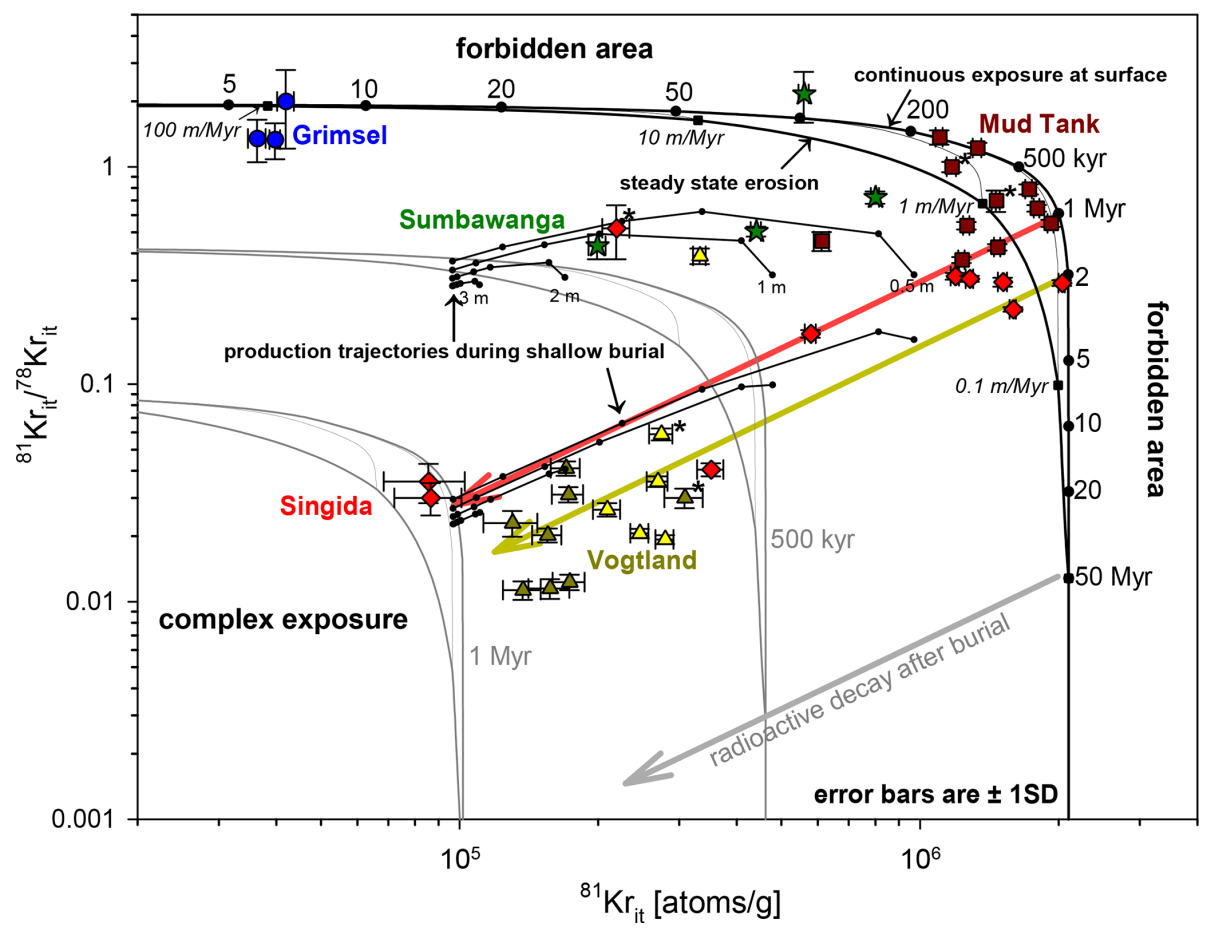

Figure 8. Unravelling histories of exposure and burial. In a ${ }^{81} \mathrm{Kr} /{ }^{78} \mathrm{Kr}_{\text {it }}$ vs. ${ }^{81} \mathrm{Kr}$ two-isotope plot, analogous to similar diagrams used for ${ }^{26} \mathrm{Al}$ and ${ }^{10} \mathrm{Be}$ (Dunai, 2010; Lal, 1991) or ${ }^{21} \mathrm{Ne}$ and ${ }^{10} \mathrm{Be}$ (Kober et al., 2009), histories of exposure and burial can be deciphered. The spallogenic ${ }^{81} \mathrm{Kr} /{ }^{78} \mathrm{Kr}_{\text {it }}$ production ratio (1.94 \pm 0.09 ; $1 \mathrm{SE}$ calculated from samples MUD-1 and MUD-11; see main text), the ${ }^{81} \mathrm{Kr}_{\mathrm{it}}$ production rate $\left(6.33 \pm 0.32\right.$ atoms $\mathrm{g}^{-1} \mathrm{yr}^{-1}$; this study) and the ${ }^{81} \mathrm{Kr}$ half-life $(229 \pm 11 \mathrm{kyr}$, Baglin, 2008) are used to define the boundaries between areas that are forbidden (no physically plausible explanation), areas that denote simple continuous exposure or steady state erosion or complex histories that include intermittent burial. Samples that are continuously exposed at the surface may be used to test the consistency of the ${ }^{81} \mathrm{Kr} /{ }^{78} \mathrm{Kr}_{\text {it }}$ production ratio and/or ${ }^{81} \mathrm{Kr}_{\text {it }}$ production rate applied. Due do the decay of ${ }^{81} \mathrm{Kr}$, the ${ }^{81} \mathrm{Kr} /{ }^{78} \mathrm{Kr}$ it ratio of exposed samples decreases with increasing exposure age until the ${ }^{81} \mathrm{Kr}$ concentration eventually saturates (production rate $=$ decay rate) after about 8-9 half-lives (this limit is dependent on the analytical uncertainties achieved). For exposures $>1 \mathrm{Myr}$, the ${ }^{81} \mathrm{Kr}_{\mathrm{it}} /{ }^{78} \mathrm{Kr}_{\text {it }}$ ratio is a direct proxy for the exposure age (Marti, 1967), independent of scaling factors or shielding as long as the latter is constant through time (Marti, 1967). Upon burial the previously acquired ${ }^{81} \mathrm{Kr}_{\mathrm{it}}$ inventory decays over time, allowing, in the case of a single period of deep burial, its duration to be determined. All samples are consistent with either continuous exposure at the Earth's surface, exhumation at a steady rate, or with histories that include burial after exposure ("complex exposure"). Samples marked with an asterisk (*) are those that were identified to contain fractionated and/or nucleogenic $\mathrm{Kr}$ (Fig. 7); results of these samples are excluded from further evaluation. The two colours used for the samples from Vogtland denote the distance they were collected downstream of their source (yellow $\sim 5 \mathrm{~km}$; dark yellow $\sim 15 \mathrm{~km}$ ). Symbols and colours for samples are the same as in Fig. 6. For two samples from Grimsel (GRIM-19-1 and 2) the error weighted means (1 SE) of duplicate and triplicate measurements are plotted. The ${ }^{81} \mathrm{Kr}_{\text {it }}$ concentrations are normalized to sea level and high latitude using LSD scaling (Lifton et al., 2014), and the standard atmosphere model to convert altitude into atmospheric pressure (Balco et al., 2008). The evolution trajectories shown are calculated using a ${ }^{81} \mathrm{Kr}_{\text {it }} /{ }^{78} \mathrm{Kr}_{\text {it }}$ production ratio of 1.94 (this study), a sea-level high-latitude ${ }^{81} \mathrm{Kr}_{\text {it }}$ production rate of 6.33 (this study), the ${ }^{81} \mathrm{Kr}_{\text {it }}$ half-life of $229 \mathrm{kyr}$ (Baglin, 2008), and a density of $2.7 \mathrm{~g} \mathrm{~cm}^{-3}$ for source rocks and/or overburden. Format of diagram after Lal (1991). The two, subordinate, steady-state erosion islands bound by the grey lines give hypothetical examples of where samples would plot had they been originally exposed at the surface and then buried at a significant depth for 500 kyr, or for $1 \mathrm{Myr}$. The two sets of example production trajectories illustrate regrowth at shallower depths (i.e. 3, 2, 1 and $0.5 \mathrm{~m}$; during 500 and $1000 \mathrm{kyr}$ of burial, respectively). Trajectories are vertically offset within each set for better visibility (i.e. the trajectories for the different burial depths actually originate from one point). Dots on the regrowth trajectories are for 0 years, 10, 50, 100, 500 kyr and $1 \mathrm{Myr}$ production, respectively.

African Rift segments (Chorowicz, 2005). The resulting localized, short-wavelength $(1-8 \mathrm{~km})$ relief is in places significant (up to $600 \mathrm{~m}$ ). The current local climate is temperate (Peel et al., 2007), rather than arid. The samples from Sumbuwanga (Fig. 8) indicate individual exhumation rates around $1 \mathrm{~m} \mathrm{Myr}^{-1}$, and all but one have had a complex ex- posure history, with burial for up to $500 \mathrm{kyr}$ and/or production at shallow depths. The order-of-magnitude-higher erosion rates inferred for source regions of Sumbawanga zircons, as compared to Singida, are commensurate with the different tectonomorphology and climatic conditions. 
The setting of the samples from Vogtland (Germany) is distinct from the other sedimentary samples in this study, as it is the only location that experienced periglacial conditions in the past (Eissmann, 2002). The area was never glaciated but was within $50 \mathrm{~km}$ of the ice margins during the largest Quaternary glaciations (Eissmann, 2002). The climate is currently temperate (Bohn and Gollub, 2006; Kreklow et al., 2019). The relief is moderate, at $200-300 \mathrm{~m}$ over $2-3 \mathrm{~km}$ scale wavelengths. The zircons' source is a kimberlitic diatreme (Schmidt et al., 2013; Modalek et al., 2009) that intruded into Palaeozoic slates 71.2 $\pm 0.8 \mathrm{Myr}$ ago (U-Pb age; Table 2). The diatreme acts as the headwaters of the drainage system investigated. The zircons from Vogtland form a cluster $(n=13$; Fig. 8$)$ that is commensurate with a long (1 to $3 \mathrm{Myr}$ ) exposure at or near the surface, or exhumation at a very low rate $\left(<0.1 \mathrm{~m} \mathrm{Myr}^{-1}\right)$, followed by a period of burial for 600 to $900 \mathrm{kyr}$ and a recent re-emergence in the active fluvial system. Samples collected further from the source (15 vs. $5 \mathrm{~km}$ ) appear to have longer burial histories (Fig. 8). The extremely low erosion rates inferred for exposure prior to burial $\left(<0.1 \mathrm{~m} \mathrm{Myr}^{-1}\right)$ are unprecedented for temperate regions in Europe, and late Quaternary erosion rates of similar moderate relief landscapes are 2 orders of magnitude faster (>10 $\mathrm{m} \mathrm{Myr}^{-1}$; Schaller et al., 2001).

The termination of the initial long exposure of the Vogtland zircons $\sim 900 \mathrm{kyr}$ ago coincides with the marked climatic shifts associated with the "0.9 Ma event" (Marine Isotope Stage 22 (MIS 22); Head and Gibbard, 2015; Mcclymont et al., 2013; Lisiecki and Raymo, 2005) during the Mid-Pleistocene Transition (MPT) (Clark et al., 2006; Head and Gibbard, 2005; Mcclymont et al., 2013). In Europe this climatic shift is associated with pronounced acceleration of river incision (Gibbard and Lewin, 2009), in part driven by increased sediment loads from periglacial hillslope processes (Gibbard and Lewin, 2009; Goodfellow and Boelhouwers, 2013). Until the Pleistocene, low-relief landscapes dominated throughout Europe (Gibbard and Lewin, 2009; Muttoni et al., 2003; Haeuselmann et al., 2007). This stasis came to an end during the MPT (Gibbard and Lewin, 2009; Muttoni et al., 2003; Haeuselmann et al., 2007), with a step change during MIS 22 (Gibbard and Lewin, 2009; Muttoni et al., 2003). The first major glaciation that followed was MIS 16 (676 to 621 kyr; Lisiecki and Raymo, 2005; Ehlers and Gibbard, 2007), which overlaps with the youngest burial ages of zircons in the cluster (Fig. 8). One zircon from this group may record a shorter burial, or significant post-burial production at a shallower depth.

From the external constraints on climate and landscape evolution in Europe (Gibbard and Lewin, 2009; Head and Gibbard, 2015; Mcclymont et al., 2013; Pena and Goldstein, 2014) and our results (Fig. 8) we assemble the following, preliminary, scenario. A formerly stable Plio-Pleistocene landscape (Gibbard and Lewin, 2009) is exposed for the first time to periglacial conditions during MIS 22 (Head and Gibbard, 2015; Pena and Goldstein, 2014). A functional vegetation cover is largely lost and periglacial hillslope processes accelerate sediment supply (Gibbard and Lewin, 2009; Goodfellow and Boelhouwers, 2013). The ensuing surge in sediment supply may have overwhelmed the transport capabilities of low-order catchments, and consequently sediments are stored on hillslopes or in the fluvial system. In the studied case, slopes would begin to be stripped of their preexisting regolith cover during MIS 22 and this would have been largely concluded by the end of MIS 16. The finding that the burial ages of the zircons seem to increase with distance from their source locations points to a long-term burial in fluvial sediments, rather than in colluvium proximal to their source. Analyses of additional material and locations are currently ongoing to test this preliminary scenario. For the purpose of this study, we note that $\mathrm{Kr}_{\mathrm{it}}$ is suitable to illuminate (Mid-)Pleistocene histories of burial and exposure.

\section{Discussion}

Our results from the suite of zircon samples taken from nearsurface sediments and bedrock demonstrate the feasibility and utility of $\mathrm{Kr}_{\mathrm{it}}$ for Earth surface science applications. Not all $\mathrm{Kr}$ isotopes are equally suitable for this purpose, and some aspects concerning the main target mineral, zircon, need consideration. In the following, we elucidate these topics, outline the required research to address current limitations and explore the potential of this novel tool for Earth surface sciences.

\subsection{The utility of $\mathrm{Kr}$ isotopes for cosmogenic applications}

The utility for each of the various $\mathrm{Kr}_{\mathrm{it}}$ isotopes is set by its relative abundance, the presence or absence of alternative production pathways (fissiogenic and/or nucleogenic), its half-life (where applicable), and its atmospheric abundance $\left({ }^{80} \mathrm{Kr} 2.25 \% ;{ }^{82} \mathrm{Kr} 11.6 \% ;{ }^{83} \mathrm{Kr} 11.5 \% ;{ }^{84} \mathrm{Kr} 57.0 \%\right.$; ${ }^{86} \mathrm{Kr} 17.3 \% ;{ }^{78} \mathrm{Kr} 0.35 \% ;{ }^{81} \mathrm{Kr} 0.5$ ppt; Buizert et al., 2014; Aregbe et al., 1996), i.e. its ubiquitous general background. Specifically, we found the following:

a. ${ }^{78} \mathrm{Kr}$ and ${ }^{81} \mathrm{Kr}$ are exclusively produced by cosmic rays, not by fission or nucleogenic reactions, and they are the rarest $\mathrm{Kr}$ isotopes in air $(0.35 \%$ and $0.5 \mathrm{ppt}$ in air; Fig. 1; (Buizert et al., 2014; Aregbe et al., 1996). These factors facilitate the detection and quantification of small amounts of $\mathrm{Kr}_{\mathrm{it}}$.

b. ${ }^{80} \mathrm{Kr}$ and ${ }^{82} \mathrm{Kr}$ may be produced by nucleonic reactions on bromine, ${ }^{79} \operatorname{Br}(n, \gamma){ }^{80} \mathrm{Kr}$ and ${ }^{81} \operatorname{Br}(n, \gamma){ }^{82} \mathrm{Kr}$. Reaction cross sections for thermal neutrons are 10.32 and 2.36 barn $\left(1.032 \times 10^{27}\right.$ and $\left.2.36 \times 10^{28} \mathrm{~m}^{2}\right)$, respectively (Soppera et al., 2014). Bromine concentrations are low in silicate minerals (Ruzie-Hamilton et al., 2016; Kendrick, 2012; Teiber et al., 2015) but often not 
constrained. The fissiogenic production of ${ }^{82} \mathrm{Kr}$ is negligible (Fig. 1; JAEA, 2011). The presence of $\mathrm{Kr}_{\text {nuc }}$ can be verified and affected samples can be excluded from further interpretation (Fig. 7).

c. ${ }^{83} \mathrm{Kr}$, which in meteorite studies is used as the most prominent $\mathrm{Kr}_{\text {iet }}$ isotope, may be produced by fission of ${ }^{238} \mathrm{U}$ (Fig. 1; Eikenberg et al., 1993; Honda et al., 2004; JAEA, 2011). Fissiogenic ${ }^{83} \mathrm{Kr}$ in zircon can be appreciable, since zircon is commonly enriched in uranium (particularly in comparison with meteorites) and $\mathrm{Kr}_{\text {fis }}$ will accumulate over the geological age of zircons (Eikenberg et al., 1993; Honda et al., 2004). Consequently, ${ }^{83} \mathrm{Kr}_{\text {it }}$ may not be quantified or used with the same ease as in meteorite studies.

d. Spallogenic production of ${ }^{84} \mathrm{Kr}$ and ${ }^{86} \mathrm{Kr}$ is (very) low compared to the other isotopes (Fig. 1; Gilabert et al., 2002), and their fissiogenic production rates are the highest (Fig. 1; Eikenberg et al., 1993; JAEA, 2011), limiting their utility as cosmogenic nuclides.

e. Finally, the very short half-life of ${ }^{85} \mathrm{Kr} \quad\left(t_{1 / 2}=\right.$ 10.7 years; Lerner, 1963) renders this isotope less suited to Earth surface science applications, though there may be interesting applications that could benefit from this. However, concentrations of ${ }^{85} \mathrm{Kr}_{\text {it }}$ will be fiendishly low, as it approaches saturation in as little as $\sim 50$ years.

From the above (a to e) it follows that ${ }^{78} \mathrm{Kr}_{\text {it }},{ }^{80} \mathrm{Kr}_{\text {it }}$, ${ }^{81} \mathrm{Kr}_{\text {it }}$ and ${ }^{82} \mathrm{Kr}_{\text {it }}$ are probably the most useful $\mathrm{Kr}_{\text {it }}$ isotopes for Earth surface science applications. Having three stable isotopes allows the separation of atmospheric, nucleogenic and fractionated components from cosmogenic $\mathrm{Kr}$ (Fig. 7). Fissiogenic production can be neglected $\left({ }^{82} \mathrm{Kr}\right)$ or excluded $\left({ }^{78,80,81} \mathrm{Kr}\right.$ ) for all four nuclides (Fig. 1). Finally, ${ }^{81} \mathrm{Kr}_{\text {it }}$ has no interference by any geochemical component (Fig. 1) and has a rather useful half-life $\left(t_{1 / 2}=229 \pm 11 \mathrm{kyr}\right.$; Baglin, 2008) for Earth surface science applications (Fig. 8).

$\mathrm{Kr}_{\mathrm{it}}$ is unique amongst the cosmogenic nuclides in that it has one long-lived radioactive $\left({ }^{81} \mathrm{Kr}\right)$ and several suitable stable isotopes (Gilabert et al., 2002; Marti, 1967). As heavy residues of their target nuclei, $\mathrm{Kr}_{\mathrm{it}}$ isotopes are not ejected from the target mineral, nor are they implanted from surrounding material, as is the case for cosmogenic ${ }^{3} \mathrm{He}$ (Dunai, 2010; Dunai et al., 2007; Larsen et al., 2019). ${ }^{78} \mathrm{Kr}_{\text {it }}$ is the only stable cosmogenic nuclide that cannot be produced by processes other than cosmogenic production during the geological lifetime of a rock, as its geochemical sources are gases of atmospheric composition, unaltered since the accretion of Earth (Trieloff et al., 2000). The absence of significant muogenic pathways of $\mathrm{Kr}$ production from $\mathrm{Zr}$ isotopes (see Sect. 1.2.2) help facilitate its use in Earth science applications.

\subsection{Zircon as target mineral}

Zircon is ubiquitous in igneous rocks and clastic sediments, occurring in granites as well as basalts (Grimes et al., 2007; Samson et al., 2018; Keller et al., 2017). Zircon abundance in igneous rocks is usually limited by the availability of zirconium, which has an average concentration of $82 \mathrm{ppm}$ in the oceanic crust (Jenner and O'Neill, 2012) and of $193 \mathrm{ppm}$ in the continental crust (Taylor and McLennan, 1985). Taking $193 \mathrm{ppm} \mathrm{Zr}$ as a guide, the average continental crust may contain $390 \mathrm{ppm}$ zircon. While many granitoid rocks have zirconium and zircon concentrations close to the continental average, some might deviate significantly (Keller et al., 2017). Zircon is amongst the most weathering-resistant minerals and can survive the weathering-erosion-sedimentationmetamorphism-melting cycle of rocks (Hoskin and Schaltegger, 2003; Belousova et al., 2002).

Zircon $\left(\mathrm{ZrSiO}_{4}\right)$ forms a continuous mixture series with hafnon $\left(\mathrm{HfSiO}_{4}\right)$. In most rocks, however, the range in $\mathrm{Hf}$ concentrations actually observed in zircon is small: $1.5 \pm 1 \mathrm{wt} \%$ (Hoskin and Schaltegger, 2003; Belousova et al., 2002; Owen, 1987). Only highly evolved rocks, such as pegmatites, syenites or carbonatites, may show significantly higher Hf concentrations (Hoskin and Schaltegger, 2003; Belousova et al., 2002). Since $\mathrm{Hf}$ does not contribute to $\mathrm{Kr}_{\mathrm{it}}$ production, its role in the target chemistry would need consideration (Hf "dilutes" the $\mathrm{Zr}$ ) when interpreting $\mathrm{Kr}_{\text {it }}$ concentrations in zircons from such evolved rocks. Combined, all other impurities in zircon are well below the percentage level (Hoskin and Schaltegger, 2003; Belousova et al., 2002) and thus need no consideration when interpreting $\mathrm{Kr}_{\text {it }}$ concentrations. Hence, in most geological contexts where zircon might be used for cosmogenic methodology, a composition of $98.5 \pm 1 \% \mathrm{ZrSiO}_{4}$ may safely be assumed (Hoskin and Schaltegger, 2003; Belousova et al., 2002; Owen, 1987), without performing a chemical assay.

Retention of noble gases in zircon is very good (Honda et al., 2004; Farley, 2007). The closure temperatures for noble gases in zircon increase with increasing atomic mass: ${ }^{4} \mathrm{He}\left(160-200{ }^{\circ} \mathrm{C}\right.$; Reiners, 2005$),{ }^{21} \mathrm{Ne}\left(400 \pm 50{ }^{\circ} \mathrm{C}\right.$; Gautheron et al., 2006), ${ }^{86} \mathrm{Kr}\left(560-580{ }^{\circ} \mathrm{C}\right.$; Honda et al., 2004), ${ }^{136} \mathrm{Xe}\left(660-750^{\circ} \mathrm{C}\right.$, Honda et al., 2004). This may be a mixed blessing for some applications of $\mathrm{Kr}_{i t}$. On the one hand, the excellent retentivity makes paleo-erosion rate studies in diagenetically altered to slightly metamorphosed rocks feasible. On the other hand, potentially incomplete resetting of the (stable) $\mathrm{Kr}_{\text {it }}$ by thermal diffusion in source rocks might complicate applications such as burial dating (Dunai, 2010). In any case, the retentivity of $\mathrm{Kr}_{\text {it }}$ under environmental conditions will be complete in structurally intact zircons. The qualifier "structurally intact" is pointing to the fact that radioactivity within the zircon ( $\alpha$-decay of $\mathrm{U}, \mathrm{Th}, \mathrm{Sm}$ ) causes cumulative radiation damage over time. This can eventually lead to complete destruction of the lattice and amorphiza- 
tion of the material (metamictization; Ewing et al., 2003). This process goes hand-in-hand with an increase in volume (lowering of density by up to $17 \%$; Ewing et al., 2003). Retention of helium in zircon decreases at cumulative al-

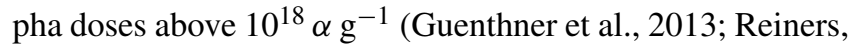
2005), and zircon remains retentive for helium at environmental temperatures up to doses of $2-4 \times 10^{18} \alpha \mathrm{g}^{-1}$ (Reiners, 2005). Since retentivity of noble gases increases with atomic mass (see above), krypton will be retained quantitatively in zircon at environmental temperatures at least up to the dose of $2-4 \times 10^{18} \alpha \mathrm{g}^{-1}$. A zircon with $1000 \mathrm{ppm} \mathrm{U}$ (with $\mathrm{Th} / \mathrm{U}=0.5$ ) requires $\sim 10^{9}$ years to receive a dose of

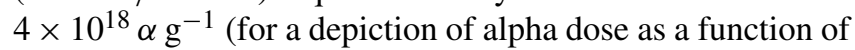
age and $U$ concentration we refer to Reiners, 2005). Thus, for most zircons, complete retentivity of krypton at environmental temperatures can be assumed. Evidence from other noble gases (Guenthner et al., 2013) and other minerals (Eikenberg et al., 1993; Ragettli et al., 1994) suggests that the retentivity of $\mathrm{Kr}_{\text {it }}$ may be an issue for highly metamict zircons. The glassy nature of highly metamict zircons also renders them more vulnerable to weathering (Ewing et al., 2011). However, it still takes intense tropical weathering (laterization) to (partially) destroy metamict zircons (Delattre et al., 2007).

\subsection{Applications in the Earth sciences}

Zircon as a target material stands out in terms of weathering resistance (Hoskin and Schaltegger, 2003; Belousova et al., 2002) and retentivity for noble gases (Honda et al., 2004; Farley, 2007). This combination of characteristics complements existing cosmogenic nuclide methodology (Dunai, 2010; Marti, 1967; Granger and Riebe, 2014; Gosse and Phillips, 2001). For instance, basin-wide denudation rates (Granger and Riebe, 2014) of lateritic regoliths, which cover large tracts of the Earth surface (e.g. Burke et al., 2008), and quartz-free lithologies such as basalts, which are important for $\mathrm{CO}_{2}$ draw-down (Dessert et al., 2003), may be reliably addressed without the bias that is introduced when target minerals perish during weathering (Granger and Riebe, 2014). The additional information obtained by combining cosmogenic nuclides with different half-lives is inherently available, as the relevant $\mathrm{Kr}_{i t}$ isotopes are measured simultaneously. The important detail that ${ }^{78} \mathrm{Kr}$ has no other sources than gases of atmospheric composition and cosmogenic production allows, in principle, the determination of paleoerosion rates from clastic sedimentary rocks of all ages.

The results presented here provide an idea of the utility of this new tool for dating changes of process rates on the Earth surface (MPT in temperate regions), or testing their notional long-term invariance (African Surface). The ability to use stable-radionuclide pairs to track the exposure and burial history of single grains of coarse sand or fine gravel helps to achieve this. However, amalgamated, multi-grain samples for $\mathrm{Kr}_{\text {it }}$ are also possible and allow averaging approaches as are routinely available for other cosmogenic nuclides (Granger and Riebe, 2014), with the added benefits of an inherent stable-radionuclide pair and the unique weathering properties of zircon.

\section{Conclusions}

From this first study of in situ-produced terrestrial krypton $\left(\mathrm{Kr}_{\mathrm{it}}\right)$ we draw the following conclusions.

1. In situ-produced cosmogenic krypton in terrestrial zircon can be analysed with the existing sector field mass spectrometry methodology. A high-resolution mass spectrometer aids resolving interferences from hydrocarbons and $\mathrm{Ar}_{2} \mathrm{H}^{+}$. Likewise, a low-blank laser extraction of $\mathrm{Kr}$ from zircon aids resolving small isotopic enrichments relative to atmospheric $\mathrm{Kr}$.

2. ${ }^{78} \mathrm{Kr},{ }^{80} \mathrm{Kr},{ }^{81} \mathrm{Kr}$ and ${ }^{82} \mathrm{Kr}$ are the most suitable $\mathrm{Kr}$ isotopes for terrestrial applications; this judgement is based on their abundance in air, the half-life of ${ }^{81} \mathrm{Kr}$, and the absence or rarity of interfering geochemical components.

3. Cross-calibration to ${ }^{10} \mathrm{Be}$ production in quartz $\left({ }^{81} \mathrm{Kr}_{\mathrm{it}}(\mathrm{zrc}) /{ }^{10} \mathrm{Be}(\mathrm{qtz})=1.545 \pm 0.045\right) \quad$ yields a production rate of ${ }^{81} \mathrm{Kr}_{\text {it }}$ in zircon of $6.33 \pm 0.32$ atoms $^{-1} \mathrm{yr}^{-1}$ at sea level and high latitude. Our measurements indicate a terrestrial ${ }^{81} \mathrm{Kr} /{ }^{78} \mathrm{Kr}_{\text {it }}$ production ratio in zircon of $1.94 \pm 0.09$ and that the air-spallogenic mixing line in ${ }^{78} \mathrm{Kr} /{ }^{82} \mathrm{Kr}$ vs. ${ }^{80} \mathrm{Kr} /{ }^{82} \mathrm{Kr}$ space (Fig. 7) has a slope of $1.682 \pm 0.015$ (uncertainties are $1 \mathrm{SD}$ ).

4. As heavy residues of spallation, $\mathrm{Kr}_{\mathrm{it}}$ nuclei are neither implanted into zircon nor ejected from zircon. Hence, $\mathrm{Kr}_{\text {it }}$ production rates are not dependent on grain size or matrix, as is the case for cosmogenic ${ }^{3} \mathrm{He}$ (Dunai, 2010; Larsen et al., 2019).

5. Interfering geochemical components and physical processes (fractionation) can be reliably identified using ${ }^{78} \mathrm{Kr},{ }^{80} \mathrm{Kr}$ and ${ }^{82} \mathrm{Kr}$, similar to the existing methodology for cosmogenic neon (three-isotope diagram; Niedermann, 2002).

6. The combination of a stable $\mathrm{Kr}_{\mathrm{it}}$ isotope (here ${ }^{78} \mathrm{Kr}_{\mathrm{it}}$ ) and radioactive ${ }^{81} \mathrm{Kr}_{\mathrm{it}}\left(t_{1 / 2}=229 \mathrm{kyr}\right.$, Baglin, 2008) allows the reconstruction of complex histories of exposure and burial, similar to the existing methodology for ${ }^{10} \mathrm{Be}$ and ${ }^{26} \mathrm{Al}$ ("banana plot"; Lal, 1991). The shorter half-life of ${ }^{81} \mathrm{Kr}$, as compared to ${ }^{26} \mathrm{Al}\left(t_{1 / 2}=708 \mathrm{kyr}\right.$, Nishiizumi, 2004), permits reconstructions of younger burial histories, as compared to existing methodology (i.e. combining ${ }^{10} \mathrm{Be}$ and ${ }^{26} \mathrm{Al}$ and assuming similar analytical uncertainties for equivalent exposure). The upper time limit for resolving burial histories should be lower than $2 \mathrm{Myr}$, with the actual values of the upper 
and lower limits dependent on the analytical uncertainties.

7. In situations with a long, continuous exposure $(>1 \mathrm{Ma})$, ${ }^{81} \mathrm{Kr}-\mathrm{Kr}$ ages, which are independent of scaling, may be calculated using the existing methodology from meteoritics (Marti, 1967; Leya et al., 2015).

8. ${ }^{78} \mathrm{Kr}$ has no sources other than gases of atmospheric composition and cosmogenic production, allowing, in principle, the determination of paleo-erosion rates from clastic sedimentary rocks of all ages.

Data availability. The underlying data for our work are provided in the Tables 1,2 and 3.

Author contributions. TJD conceptualized the study and designed the noble gas experiments. Investigation and formal analysis of data were carried out by all authors. TJD prepared the paper with contributions from SAB and AG.

Competing interests. The contact author has declared that neither they nor their co-authors have any competing interests.

Disclaimer. Publisher's note: Copernicus Publications remains neutral with regard to jurisdictional claims in published maps and institutional affiliations.

Acknowledgements. Tibor János Dunai would like to thank Sven Kreher (Goldmuseum Buchwald) for providing the zircons from Vogtland, sharing detailed information on the sampling sites and hands-on experience with washing zircons. Many thanks to Georgina King and Peter Abbott for collecting and documenting sample GRIM-1. The safe execution of the high-temperature extractions was enabled by Andreas Vogt. Tibor János Dunai owes the integrity of the laser extraction line and probably his health to these efforts, and would like to express his special thanks. Tibor János Dunai is very grateful to Andreas Knecht (PSI) for pointing out errors in initial estimates of muon reaction probabilities.

Financial support. This research has been supported by the Deutsche Forschungsgemeinschaft (project nos. 259990027 and 268236062 - SFB 1211).

Review statement. This paper was edited by Marissa Tremblay and reviewed by Stephen Cox and Michal Ben-Israel.

\section{References}

Arblaster, J. W.: Thermodynamic Properties of Tantalum, J. Phase Equilib. Diff., 39, 255-272, https://doi.org/10.1007/s11669-0180627-2, 2018.

Aregbe, Y., Valkiers, S., Mayer, K., and DeBievre, P.: Comparative isotopic measurements on xenon and krypton, Int J. Mass Spectrom., 153, L1-L5, https://doi.org/10.1016/01681176(96)04368-6, 1996.

Australian Vermiculite Industries: Mine Closure Plan Mud Tank Operation MIN 165, available at: https: //geoscience.nt.gov.au/gemis/ntgsjspui/bitstream/1/80230/3/ MLS165_2014_AS_03_APPENDIX2_MCP.pdf (last access: 16 January 2022), 2013.

Baglin, C. M.: Nuclear Data Sheets for $A=81$, Nucl. Data Sheets, 109, 2257-2437, https://doi.org/10.1016/j.nds.2008.09.001, 2008.

Balco, G.: Glacier Change and Paleoclimate Applications of Cosmogenic-Nuclide Exposure Dating, Annu. Rev. Earth Pl. Sc., 48, 21-48, https://doi.org/10.1146/annurev-earth-081619052609, 2020 .

Balco, G., Stone, J. O., Lifton, N. A., and Dunai, T. J.: A complete and easily accessible means of calculating surface exposure ages or erosion rates from ${ }^{10} \mathrm{Be}$ and ${ }^{26} \mathrm{Al}$ measurements, Quat. Geochronol., 3, 174-195, https://doi.org/10.1016/j.quageo.2007.12.001, 2008.

Belousova, E. A., Griffin, W. L., O'Reilly, S. Y., and Fisher, N. I.: Igneous zircon: trace element composition as an indicator of source rock type, Contrib. Mineral. Petr., 143, 602-622, https://doi.org/10.1007/s00410-002-0364-7, 2002.

Binnie, S. A., Dunai, T. J., Voronina, E., Goral, T., Heinze, S., and Dewald, A.: Separation of Be and Al for AMS using single-step column chromatography, Nucl. Instrum. Meth. B, 361, 397-401, https://doi.org/10.1016/j.nimb.2015.03.069, 2015.

Binnie, S. A., Dewald, A., Heinze, S., Voronina, E., Hein, A., Wittmann, H., von Blanckenburg, F., Hetzel, R., Christl, M. Schaller, M., Leanni, L., Hippe, K., Vockenhuber, C., Ivy-Ochs, S., Maden, C., Fulop, R. H., Fink, D., Wilcken, K. M., Fujioka, T., Fabel, D., Freeman, S., Xu, S., Fifield, L. K., Akcar, N., Spiegel, C., Dunai, T. J., Aumaitre, G., Bourles, D. L., Keddadouche, K., and Team, A.: Preliminary results of CoQtz-N: A quartz reference material for terrestrial in situ cosmogenic ${ }^{10} \mathrm{Be}$ and ${ }^{26} \mathrm{Al}$ measurements, Nucl. Instrum. Meth. B, 456, 203-212, https://doi.org/10.1016/j.nimb.2019.04.073, 2019.

Bohn, U. and Gollub, G.: The use and application of the map of the natural vegetation of Europe with particular refernce to Germany, Biol. Environ., 106B, 199-213, 2006.

Broadley, M. W., Barry, P. H., Bekaert, D. V., Byrne, D. J., Caracausi, A., Ballentine, C. J., and Marty, B.: Identification of chondritic krypton and xenon in Yellowstone gases and the timing of terrestrial volatile accretion, P. Natl. Acad. Sci. USA, 117, 13997-14004, https://doi.org/10.1073/pnas.2003907117, 2020.

Buizert, C., Baggenstos, D., Jiang, W., Purtschert, R., Petrenko, V. V., Lu, Z. T., Muller, P., Kuhl, T., Lee, J., Severinghaus, J. P., and Brook, E. J.: Radiometric ${ }^{81} \mathrm{Kr}$ dating identifies 120,000-year-old ice at Taylor Glacier, Antarctica, P. Natl. Acad. Sci. USA, 111, 6876-6881, https://doi.org/10.1073/pnas.1320329111, 2014. 
Burgess, R., Cartigny, P., Harrison, D., Hobson, E., and Harris, J.: Volatile composition of microinclusions in diamonds from the Panda kimberlite, Canada: Implications for chemical and isotopic heterogeneity in the mantle, Geochim. Cosmochim. Ac., 73, 1779-1794, https://doi.org/10.1016/j.gca.2008.12.025, 2009.

Burke, K., and Gunnell, Y.: The African Erosion Surface: A Continental-Scale Synthesis of Geomorphology, Tectonics, and Environmental Change over the Past 180 Million Years, in: The African Erosion Surface: A Continental-Scale Synthesis of Geomorphology, Tectonics, and Environmental Change over the Past 180 Million Years, Geological Society of America, vol. 201, 166, ISBN 9780813712017, https://doi.org/10.1130/2008.1201, 2008.

Burnard, P., Zimmermann, L., and Sano, Y.: The Noble Gases as Geochemical Tracers: History and Background, in: The Noble Gases as Geochemical Tracers, edited by: Burnard, P., Springer Berlin Heidelberg, Berlin, Heidelberg, 1-15, https://doi.org/10.1007/978-3-642-28836-4_1, 2013.

Chorowicz, J.: The East African rift system, J. Afr. Earth Sci., 43, 379-410, https://doi.org/10.1016/j.jafrearsci.2005.07.019, 2005.

Clark, P. U., Archer, D., Pollard, D., Blum, J. D., Rial, J. A., Brovkin, V., Mix, A. C., Pisias, N. G., and Roy, M.: The middle Pleistocene transition: characteristics, mechanisms, and implications for long-term changes in atmospheric $p \mathrm{CO}_{2}$, Quaternary Sci. Rev., 25, 3150-3184, 2006.

Crohn, P. W. and Moore, D. H.: The Mud Tank carbonatite, Strangways Range, Central Australia, BMR J. Aust. Geol. Geop., 9, 13-18, 1984.

Currie, K. L., Knutson, J., and Temby, P. A.: The Mud Tank carbonatite complex, Central Australia - An example of metasomatism at midcrustal levels, Contrib. Mineral. Petr., 109, 326-339, https://doi.org/10.1007/bf00283322, 1992.

Delattre, S., Utsunomiya, S., Ewing, R. C., Boeglin, J. L., Braun, J. J., Balan, E., and Calas, G.: Dissolution of radiationdamaged zircon in lateritic soils, Am. Mineral., 92, 1978-1989, https://doi.org/10.2138/am.2007.2514, 2007.

Dessert, C., Dupré, B., Gaillardet, J., François, L. M., and Allègre, C. J.: Basalt weathering laws and the impact of basalt weathering on the global carbon cycle, Chem. Geol., 202, 257-273, https://doi.org/10.1016/j.chemgeo.2002.10.001, 2003.

Dewald, A., Heinze, S., Jolie, J., Zilges, A., Dunai, T., Rethemeyer, J., Melles, M., Staubwasser, M., Kuczewski, B., Richter, J., Radtke, U., von Blanckenburg, F., and Klein, M.: CologneAMS, a dedicated center for accelerator mass spectrometry in Germany, Nucl. Instrum. Meth. B, 294, 18-23, https://doi.org/10.1016/j.nimb.2012.04.030, 2013.

Dunai, T. J.: Cosmogenic Nuclides: Principles, concepts and applications in the Earth surface sciences, 1st edn., Cambridge University Press, https://doi.org/10.1017/CBO9780511804519, 2010.

Dunai, T. J., Stuart, F. M., Pik, R., Burnard, P., and Gayer, E.: Production of ${ }^{3} \mathrm{He}$ in crustal rocks by cosmogenic thermal neutrons, Earth Planet. Sc. Lett., 258, 228-236, https://doi.org/10.1016/j.epsl.2007.03.031, 2007.

Ehlers, J. and Gibbard, P. L.: The extent and chronology of Cenozoic Global Glaciation, Quatern. Int., 164-165, 6-20, https://doi.org/10.1016/j.quaint.2006.10.008, 2007.

Eikenberg, J., Signer, P., and Wieler, R.: U-Xe, U-Kr, and U-Pb systematics for uranium minerals and investigations of the produc- tion of nucleogenic neon and argon, Geochim. Cosmochim. Ac., 57, 1053-1069, 1993.

Eissmann, L.: Quaternary geology of eastern Germany (Saxony, Saxon-Anhalt, South Brandenburg, Thüringia), type area of the Elsterian and Saalian Stages in Europe, Quaternary Sci. Rev., 21, 1275-1346, https://doi.org/10.1016/S0277-3791(01)00075$0,2002$.

Ewing, R. C., Meldrum, A., Wang, L. M., Weber, W. J., and Corrales, L. R.: Radiation effects in zircon, in: Zircon, edited by: Hanchar, J. M. and Hoskin, P. W. O., Rev. Mineral. Geochem., 53, 387-425, https://doi.org/10.2113/0530387, 2003.

Ewing, R. C., Haaker, R. F., and Lutze, W.: Leachability of Zircon as a Function of Alpha Dose, MRS Online Proceedings Library, 11, 389, https://doi.org/10.1557/PROC-11-389, 2011.

Farley, K. A.: He diffusion systematics in minerals: Evidence from synthetic monazite and zircon structure phosphates, Geochim. Cosmochim. Ac., 71, 4015-4052, 2007.

Gain, S. E. M., Greau, Y., Henry, H., Belousova, E., Dainis, I., Griffin, W. L., and O'Reilly, S. Y.: Mud Tank Zircon: Long-Term Evaluation of a Reference Material for U-Pb Dating, Hf-Isotope Analysis and Trace Element Analysis, Geostand. Geoanal. Res., 43, 339-354, https://doi.org/10.1111/ggr.12265, 2019.

Gautheron, C. E., Tassan-Got, L., and Farley, K. A.: (UTh)/Ne chronometry, Earth Planet. Sc. Lett., 243, 520-535, https://doi.org/10.1016/j.epsl.2006.01.025, 2006.

Gerdes, A. and Zeh, A.: Zircon formation versus zircon alteration New insights from combined $\mathrm{U}-\mathrm{Pb}$ and $\mathrm{Lu}-\mathrm{Hf}$ in-situ LA-ICPMS analyses, and consequences for the interpretation of Archean zircon from the Central Zone of the Limpopo Belt, Chem. Geol., 261, 230-243, https://doi.org/10.1016/j.chemgeo.2008.03.005, 2009.

Gibbard, P. L. and Lewin, J.: River incision and terrace formation in the Late Cenozoic of Europe, Tectonophysics, 474, 41-55, https://doi.org/10.1016/j.tecto.2008.11.017, 2009.

Gilabert, E., Lavielle, B., Michel, R., Leya, I., Neumann, S., and Herpers, U.: Production of krypton and xenon isotopes in thick stony and iron targets isotropically irradiated with $1600 \mathrm{MeV}$ protons, Meteorit. Planet. Sci., 37, 951-976, https://doi.org/10.1111/j.1945-5100.2002.tb00869.x, 2002.

Goodfellow, B. and Boelhouwers, J.: Hillslope Processes in Cold Environments: An illustration of High Latitude Hillslope Processes and Forms, in: Treatise of Geomorphology, edited by: John, F. S., Elsevier, 320-336, ISBN 9780123747396, 2013.

Gosse, J. C. and Phillips, F. M.: Terrestrial in situ cosmogenic nuclides: theory and application, Quaternary Sci. Rev., 20, 14751560, 2001.

Granger, D. E. and Riebe, C. S.: 7.12 - Cosmogenic Nuclides in Weathering and Erosion, in: Treatise on Geochemistry, second edn., edited by: Holland, H. D. and Turekian, K. K., Elsevier, Oxford, 401-436, https://doi.org/10.1016/B978-0-08095975-7.00514-3, 2014.

Grimes, C. B., John, B. E., Kelemen, P. B., Mazdab, F. K., Wooden, J. L., Cheadle, M. J., Hanghoj, K., and Schwartz, J. J.: Trace element chemistry of zircons from oceanic crust: A method for distinguishing detrital zircon provenance, Geology, 35, 643-646, https://doi.org/10.1130/g23603a.1, 2007.

Guenthner, W. R., Reiners, P. W., Ketcham, R. A., Nasdala, L., and Giester, G.: Helium diffusion in natural zircon: radiation damage, anisotropy, and the interpretation of zircon 
(U-Th)/He thermochronology, Am. J. Sci., 313, 145-198, https://doi.org/10.2475/03.2013.01, 2013.

Haeuselmann, P., Granger, D. E., Jeannin, P. Y., and Lauritzen, S. E.: Abrupt glacial valley incision at $0.8 \mathrm{Ma}$ dated from cave deposits in Switzerland, Geology, 35, 143-146, 2007.

Harrison, T., Msuya, C. P., Murray, A. M., Jacobs, B. F., Báez, A. M., Mundil, R., and Ludwig, K. R.: Paleontological Investigations at the Eocene Locality of Mahenge in North-Central Tanzania, East Africa, in: Eocene Biodiversity: Unusual Occurrences and Rarely Sampled Habitats, edited by: Gunnell, G. F., Springer US, Boston, MA, 39-74, https://doi.org/10.1007/978-14615-1271-4_2, 2001.

Head, M. J. and Gibbard, P. L.: Early-middle Pleistocene transitions: the land-ocean evidence, Geol. Soc. Spec. Publ., 247, 1-18 , 2005.

Head, M. J. and Gibbard, P. L.: Early-Middle Pleistocene transitions: Linking terrestrial and marine realms, Quatern. Int., 389, 7-46, https://doi.org/10.1016/j.quaint.2015.09.042, 2015.

Hettmann, K., Siebel, W., Spiegel, C., and Reinecker, J.: Granite genesis and migmatization in the western Aar Massif, Switzerland, Neues Jb. Miner. Abh., 186, 309-320, https://doi.org/10.1127/0077-7757/2009/0150, 2009.

Hoch, M., Nakata, M., and Johnson, H. L.: Vapor pressure of inorganic substances. XII. Zirconium Dioxide, J. Am. Soc., 76, 2651-2652, https://doi.org/10.1021/ja01639a014, 1954.

Honda, M., Nutman, A. P., Bennett, V. C., and Yatsevich, I.: Radiogenic, nucleogenic and fissiogenic noble gas compositions in early Archaean magmatic zircons from Greenland, Geochem. J., 38, 265-269, https://doi.org/10.2343/geochemj.38.265, 2004.

Hoskin, P. W. O. and Schaltegger, U.: The composition of zircon and igneous and metamorphic petrogenesis, in: Zircon, edited by: Hanchar, J. M. and Hoskin, P. W. O., Rev. Mineral. Geochem., 53, 27-62, https://doi.org/10.2113/0530027, 2003.

Japan Atomic Energy Agency (JAEA): JENDL FP Fission Yields Data File 2011, JAEA [dataset], available at: https://wwwndc. jaea.go.jp/cgi-bin/FPYfig (last acess: 16 January 2022), 2011.

Jenner, F. E. and O'Neill, H. S.: Analysis of 60 elements in 616 ocean floor basaltic glasses, Geochem. Geophy. Geosy., 13, Q02005, https://doi.org/10.1029/2011gc004009, 2012.

Kabete, J. M., Groves, D. I., McNaughton, N. J., and Mruma, A. H.: A new tectonic and temporal framework for the Tanzanian Shield: Implications for gold metallogeny and undiscovered endowment, Ore Geol. Rev., 48, 88-124, https://doi.org/10.1016/j.oregeorev.2012.02.009, 2012.

Kaiser, A., Lobert, M., and Telle, R.: Thermal stability of zircon $\left(\mathrm{ZrSiO}_{4}\right)$, J. Eur. Ceram. Soc., 28, 2199-2211, https://doi.org/10.1016/j.jeurceramsoc.2007.12.040, 2008.

Kamenetsky, V. S., Golovin, A. V., Maas, R., Giuliani, A., Kamenetsky, M. B., and Weiss, Y.: Towards a new model for kimberlite petrogenesis: Evidence from unaltered kimberlites and mantle minerals, Earth-Sci. Rev., 139, 145-167, https://doi.org/10.1016/j.earscirev.2014.09.004, 2014.

Kaneoka, I.: Rare gas isotopes and mass fractionation: an indicator of gas transport into or from a magma, Earth Planet. Sc. Lett., 48, 284-292, 1980.

Keller, C. B., Boehnke, P., and Schoene, B.: Temporal variation in relative zircon abundance throughout Earth history, Geochemical Perspectives Letters, 3, 179-189, https://doi.org/10.7185/geochemlet.1721, 2017.
Kendrick, M. A.: High precision $\mathrm{Cl}, \mathrm{Br}$ and I determinations in mineral standards using the noble gas method, Chem. Geol., 292 , 116-126, https://doi.org/10.1016/j.chemgeo.2011.11.021, 2012.

King, L.: The geomorphology of central and southern Africa, in: Biogeography and Ecology of Southern Africa, edited by: Werger, M. J. A., Springer Netherlands, Dordrecht, 1-17, https://doi.org/10.1007/978-94-009-9951-0_1, 1978.

Kober, F., Ivy-Ochs, S., Zeilinger, G., Schlunegger, F., Kubik, P. W., Baur, H., and Wieler, R.: Complex multiple cosmogenic nuclide concentration and histories in the arid Rio Lluta catchment, northern Chile, Earth Surf. Proc. Land., 34, 398-412, https://doi.org/10.1002/esp.1748, 2009.

Kohl, C. and Nishiizumi, K.: Chemical isolation of quartz for measurement of in-situ-produced cosmogenic nuclides, Geochim. Cosmochim. Ac., 56, 3583-3587, 1992.

Kreklow, J., Tetzlaff, B., Kuhnt, G., and Burkhard, B.: A Rainfall Data Intercomparison Dataset of RADKLIM, RADOLAN, and Rain Gauge Data for Germany, Data, 4, 118, https://doi.org/10.3390/data4030118, 2019.

Lal, D.: Cosmic ray labeling of erosion surfaces: in situ nuclide production rates and erosion models, Earth Planet. Sc. Lett., 104, 424-439, 1991.

Larsen, I. J., Farley, K. A., and Lamb, M. P.: Cosmogenic ${ }^{3}$ He production rate in ilmenite and the redistribution of spallation ${ }^{3} \mathrm{He}$ in fine-grained minerals, Geochim. Cosmochim. Ac., 265, 1931, https://doi.org/10.1016/j.gca.2019.08.025, 2019.

Lerner, J.: Half-life of ${ }^{85} \mathrm{Kr}$, J. Inorg. Nucl. Chem., 25, 749-757, https://doi.org/10.1016/0022-1902(63)80357-7, 1963.

Leya, I., Gilabert, E., Lavielle, B., Wiechert, U., and Wieler, R.: Production rates for cosmogenic krypton and argon isotopes in $\mathrm{H}-$ Chondrites with known ${ }^{36} \mathrm{Cl}_{-}{ }^{36} \mathrm{Ar}$ ages, Antarct. Meteorite Res., 17, 185-199, 2004.

Leya, I., Dalcher, N., Vogel, N., Wieler, R., Caffee, M. W., Welten, K. C., and Nishiizumi, K.: Calibration of cosmogenic noble gas production based on ${ }^{36} \mathrm{Cl}^{36} \mathrm{Ar}$ ages. Part 2 . The ${ }^{81} \mathrm{Kr}$ $\mathrm{Kr}$ dating technique, Meteorit. Planet. Sci., 50, 1863-1879, https://doi.org/10.1111/maps.12515, 2015.

Lifshitz, M. and Singer, P.: Nuclear excitation function and particle emission from complex nuclei following muon capture, Phys. Rev. C, 22, 2135-2150, https://doi.org/10.1103/PhysRevC.22.2135, 1980.

Lifton, N., Sato, T., and Dunai, T. J.: Scaling in situ cosmogenic nuclide production rates using analytical approximations to atmospheric cosmic-ray fluxes, Earth Planet. Sc. Lett., 386, 149-160, https://doi.org/10.1016/j.epsl.2013.10.052, 2014.

Lisiecki, L. E. and Raymo, M. E.: A Pliocene-Pleistocene stack of 57 globally distributed benthic $\delta^{18} \mathrm{O}$ records, Paleoceanography, 20, PA10003, https://doi.org/10.1029/2004PA001071, 2005.

Ludwig, K. R.: User's manual for Isoplot 3.75, 77 pp., available at: https://www.geocalculate.com/wp-content/uploads/2019/10/ Isoplot3_75-4_15manual.pdf (last access: 16 January 2022), 2012.

Mannard, G. W.: The Geology of the Singida Kimberlite Pipes, Tanganyika, Geological Sciences, $\mathrm{PhD}$ thesis, McGill University, Montreal, 377 pp., available at: https://escholarship.mcgill.ca/ concern/theses/sq87bv51d (last access: 16 January 2022), 1962.

Marti, K.: Mass-spectrometric detection of cosmic-ray-produced ${ }^{81} \mathrm{Kr}$ in meteorites and possiblity of $\mathrm{Kr}-\mathrm{Kr}$ dating, Phys. 
Rev. Lett., 18, 264, https://doi.org/10.1103/PhysRevLett.18.264, 1967.

Marti, K., Eberhardt, P., and Geiss, J.: Spallation, fission and neutron capture anomalies in meteoritic Krypton and Xenon, Z. Naturforsch. Pt. A, 21, 398-413, 1966.

Martin, L. C. P., Blard, P. H., Balco, G., Lave, J., Delunel, R., Lifton, N., and Laurent, V.: The CREp program and the ICE-D production rate calibration database: A fully parameterizable and updated online tool to compute cosmic ray exposure ages, Quat. Geochronol., 38, 25-49, https://doi.org/10.1016/j.quageo.2016.11.006, 2017.

Mason, B., Nelon, J. A., Muir, P., and Taylor, S. R.: The compostion of the Chassigny meteorite, Meteoritics, 11, 21-27, https://doi.org/10.1111/j.1945-5100.1976.tb00311.x, 1976.

McClymont, E. L., Sosdian, S. M., Rosell-Melé, A., and Rosenthal, Y.: Pleistocene sea-surface temperature evolution: Early cooling, delayed glacial intensification, and implications for the midPleistocene climate transition, Earth-Sci. Rev., 123, 173-193, https://doi.org/10.1016/j.earscirev.2013.04.006, 2013.

Measday, D. F.: The nuclear physics of muon capture, Phys. Rep., 354, 243-409, https://doi.org/10.1016/s0370-1573(01)00012-6, 2001.

Modalek, W., Seifert, G., and Weiß, S.: Edle Zirkone aus dem Sächsischen Vogtland, Lapis, 34, 13-26, 2009.

Muttoni, G., Carcano, C., Garzanti, E., Ghielmi, M., Piccin, A., Pini, R., Rogledi, S., and Sciunnach, D.: Onset of major Pleistocene glaciations in the Alps, Geology, 31, 989-992, https://doi.org/10.1130/g19445.1, 2003.

Niedermann, S.: Cosmic-ray-produced noble gases in terrestrial rocks: dating tools for surface processes, Rev. Mineral. Geochem., 47, 731-784, 2002.

Niedermann, S., Schaefer, J. M., Wieler, R., and Naumann, R.: The production of cosmogenic ${ }^{38} \mathrm{Ar}$ from calcium in terrestrial pyroxene, Earth Planet. Sc. Lett., 257, 596-608, 2007.

Nishiizumi, K.: Preparation of ${ }^{26} \mathrm{Al}$ AMS standards, Nucl. Instrum. Meth. B, 223, 388-392, 2004.

Nishiizumi, K., Imamura, M., Caffee, M. W., Southon, J. R., Finkel, R. C., and McAninch, J.: Absolute calibration of ${ }^{10} \mathrm{Be}$ AMS standards, Nucl. Instrum. Meth. B, 258, 403-413, 2007.

Oostingh, K. F., Jourdan, F., Danisik, M., and Evans, N. J.: Advancements in cosmogenic ${ }^{38} \mathrm{Ar}$ exposure dating of terrestrial rocks, Geochim. Cosmochim. Ac., 217, 193-218, https://doi.org/10.1016/j.gca.2017.07.043, 2017.

Owen, M. R.: Hafnium content of detrital zircons, a new tool for provenance study, J. Sediment. Petrol., 57, 824-830, 1987.

Peel, M. C., Finlayson, B. L., and McMahon, T. A.: Updated world map of the Köppen-Geiger climate classification, Hydrol. Earth Syst. Sci., 11, 1633-1644, https://doi.org/10.5194/hess-11-16332007, 2007.

Pena, L. D. and Goldstein, S. L.: Thermohaline circulation crisis and impacts during the mid-Pleistocene transition, Science, 345, 318-322, https://doi.org/10.1126/science.1249770, 2014.

Ragettli, R. A., Hebeda, E. H., Signer, P., and Wieler, R.: Uraniumxenon chronology: precise determination of $\lambda_{\mathrm{sf} *}^{136} \mathrm{Y}_{\mathrm{sf}}$ for spontaneous fission of ${ }^{238} \mathrm{U}$, Earth Planet. Sc. Lett., 128, 653-670, 1994.

Reiners, P. W.: Zircon (U-Th)/He Thermochronometry, Rev. Mineral. Geochem., 58, 151-179, https://doi.org/10.2138/rmg.2005.58.6, 2005.
Renne, P. R., Farley, K. A., Becker, T. A., and Sharp, W. D.: Terrestrial cosmogenic argon, Earth Planet. Sc. Lett., 188, 435-440, 2001.

Ritter, B., Vogt, A., and Dunai, T. J.: Technical Note: Noble gas extraction procedure and performance of the Cologne Helix MC Plus multi-collector noble gas mass spectrometer for cosmogenic neon isotope analysis, Geochronology, 3, 421-431, https://doi.org/10.5194/gchron-3-421-2021, 2021.

Ruzie-Hamilton, L., Clay, P. L., Burgess, R., Joachim, B., Ballentine, C. J., and Turner, G.: Determination of halogen abundances in terrestrial and extraterrestrial samples by the analysis of noble gases produced by neutron irradiation, Chem. Geol., 437, 77-87, https://doi.org/10.1016/j.chemgeo.2016.05.003, 2016.

Saldanha, R., Back, H. O., Tsang, R. H. M., Alexander, T., Elliott, S. R., Ferrara, S., Mace, E., Overman, C., and Zalavadia, M.: Cosmogenic production of ${ }^{39} \mathrm{Ar}$ and ${ }^{37} \mathrm{Ar}$ in argon, Phys. Rev. C, 100, 024608, https://doi.org/10.1103/PhysRevC.100.024608, 2019.

Samson, S. D., Moecher, D. P., and Satkoski, A. M.: Inherited, enriched, heated, or recycled? Examining potential causes of Earth's most zircon fertile magmatic episode, Lithos, 314, 350 359, https://doi.org/10.1016/j.lithos.2018.06.015, 2018.

Schaller, M., von Blanckenburg, F., Hovius, N., and Kubik, P. W.: Large-scale erosion rates from in situ produced cosmogenic nuclides in European river sediments, Earth Planet. Sc. Lett., 188 441-458, 2001.

Schaltegger, U. and Corfu, F.: The age and source of late Hercynian magmatism in the Central Alps - Evidence from precise U-Pb ages and initial Hf isotopes, Contrib. Mineral. Petr., 111, 329344, https://doi.org/10.1007/bf00311195, 1992.

Schick, H. L.: A Thermodynamic Analysis of the High-temperature Vaporization Properties of Silica, Chem. Rev., 60, 331-362, https://doi.org/10.1021/cr60206a002, 1960.

Schmidt, A., Nowaczyk, N., Kampf, H., Schuller, I., Flechsig, C., and Jahr, T.: Origin of magnetic anomalies in the large Ebersbrunn diatreme, W Saxony, Germany, B. Volcanol., 75, 766, https://doi.org/10.1007/s00445-013-0766-6, 2013.

Soppera, N., Bossant, M., and Dupont, E.: Janis 4: An improved version of the NEA Java-based Nuclear Date Information System, Nucl. Data Sheets, 120, 294-296, https://doi.org/10.1016/j.nds.2014.07.071, 2014.

Stone, J. O., Evans, N. J., Fifield, L. K., Allan, G. L., and Cresswell, R. G.: Cosmogenic chlorine-36 production in calcite by muons, Geochim. Cosmochim. Ac., 62, 433-454, 1998.

Strashnov, I. and Gilmour, J. D.: ${ }^{81} \mathrm{Kr}-\mathrm{Kr}$ cosmic ray exposure ages of individual chondrules from Allegan, Meteorit. Planet. Sci., 48, 2430-2440, https://doi.org/10.1111/maps.12228, 2013.

Struck, M., Jansen, J. D., Fujioka, T., Codilean, A. T., Fink, D., Egholm, D. L., Fülöp, R.-H., Wilcken, K. M., and Kotevski, S.: Soil production and transport on postorogenic desert hillslopes quantified with ${ }^{10} \mathrm{Be}$ and ${ }^{26} \mathrm{Al}$, GSA Bulletin, 130, 1017-1040, https://doi.org/10.1130/b31767.1, 2018a.

Struck, M., Jansen, J. D., Fujioka, T., Codilean, A. T., Fink, D., Fülöp, R.-H., Wilcken, K. M., Price, D. M., Kotevski, S., Fifield, L. K., and Chappell, J.: Tracking the ${ }^{10} \mathrm{Be}-{ }^{26} \mathrm{Al}$ source-area signal in sediment-routing systems of arid central Australia, Earth Surf. Dynam., 6, 329-349, https://doi.org/10.5194/esurf-6-3292018, 2018b. 
Sturchio, N. C., Du, X., Purtschert, R., Lehmann, B. E., Sultan, M., Patterson, L. J., Lu, Z. T., Muller, P., Bigler, T., Bailey, K., O’Connor, T. P., Young, L., Lorenzo, R., Becker, R., El Alfy, Z., El Kaliouby, B., Dawood, Y., and Abdallah, A. M. A.: One million year old groundwater in the Sahara revealed by krypton-81 and chlorine-36, Geophys. Res. Lett., 31, L05503, https://doi.org/10.1029/2003g1019234, 2004.

Taylor, S. R. and McLennan, S. M.: The continental crust: its composition and evolution, Geoscience Texts, Blackwell, Oxford, ISBN 0632011483, 1985.

Teiber, H., Scharrer, M., Marks, M. A. W., Arzamastsev, A. A., Wenzel, T., and Markl, G.: Equilibrium partitioning and subsequent re-distribution of halogens among apatite-biotite-amphibole assemblages from mantle-derived plutonic rocks: Complexities revealed, Lithos, 220, 221-237, https://doi.org/10.1016/j.lithos.2015.02.015, 2015.

Trieloff, M., Kunz, J., Clague, D. A., Harrison, D., and Allegre, C. J.: The nature of pristine noble gases in mantle plumes, Science, 288, 1036-1038, https://doi.org/10.1126/science.288.5468.1036, 2000.

Uppala, S. M., Kållberg, P. W., Simmons, A. J., Andrae, U., Bechtold, V. D. C., Fiorino, M., Gibson, J. K., Haseler, J., Hernandez, A., Kelly, G. A., Li, X., Onogi, K., Saarinen, S., Sokka, N., Allan, R. P., Andersson, E., Arpe, K., Balmaseda, M. A., Beljaars, A. C. M., Berg, L. V. D., Bidlot, J., Bormann, N., Caires, S., Chevallier, F., Dethof, A., Dragosavac, M., Fisher, M., Fuentes, M., Hagemann, S., Hólm, E., Hoskins, B. J., Isaksen, L., Janssen, P. A. E. M., Jenne, R., Mcnally, A. P., Mahfouf, J.-F., Morcrette, J.-J., Rayner, N. A., Saunders, R. W., Simon, P., Sterl, A., Trenberth, K. E., Untch, A., Vasiljevic, D., Viterbo, P., and Woollen, J.: The ERA-40 re-analysis, Q. J. Roy. Meteorol. Soc., 131, 2961-3012, https://doi.org/10.1256/qj.04.176, 2005. von Egidy, T. and Hartmann, F. J.: Average muonic coulomb capture probabilities for 65 elements, Phys. Rev. A, 26, 2355-2360, https://doi.org/10.1103/PhysRevA.26.2355, 1982.

Wirsig, C., Zasadni, J., Ivy-Ochs, S., Christl, M., Kober, F., and Schluchter, C.: A deglaciation model of the Oberhasli, Switzerland, J. Quaternary Sci., 31, 46-59, https://doi.org/10.1002/jqs.2831, 2016.

Woodhead, J. D. and Hergt, J. M.: A preliminary appraisal of seven natural zircon reference materials for in situ Hf isotope determination, Geostand. Geoanal. Res., 29, 183-195, https://doi.org/10.1111/j.1751-908X.2005.tb00891.x, 2005.

Wyttenbach, A., Baertschi, P., Bajo, S., Hadermann, J., Junker, K., Katcoff, S., Hermes, E. A., and Pruys, H. S.: Probabilites of muon induced nuclear-reactions involving charged-particle emission, Nucl. Phys. A, 294, 278-292, https://doi.org/10.1016/03759474(78)90218-x, 1978.

Zimmermann, L., Avice, G., Blard, P.-H., Marty, B., Füri, E., and Burnard, P. G.: A new all-metal induction furnace for noble gas extraction, Chem. Geol., 480, 86-92, https://doi.org/10.1016/j.chemgeo.2017.09.018, 2018. 